\title{
Participatory research results from training with the Mabinti Tushike Hatamu out-of-school girls program: Tanzania 2015
}

\author{
Kelly Hallman \\ Population Council \\ Ilan Cerna-Turoff \\ Neema Matee
}

Follow this and additional works at: https://knowledgecommons.popcouncil.org/departments_sbsr-pgy

Part of the Community Health and Preventive Medicine Commons, Demography, Population, and Ecology Commons, Family, Life Course, and Society Commons, Gender and Sexuality Commons, International Public Health Commons, and the Women's Health Commons How does access to this work benefit you? Let us know!

\section{Recommended Citation}

Hallman, Kelly, Ilan Cerna-Turoff, and Neema Matee. 2015. "Participatory research results from training with the Mabinti Tushike Hatamu out-of-school girls program: Tanzania 2015." New York: Population Council. 


\section{PARTICIPATORY RESEARCH} RESULTS FROM TRAINING WITH THE MABINTI TUSHIKE HATAMU OUT-OF-SCHOOL GIRLS PROGRAM

\section{TANZANIA 2015}




\title{
Participatory Research Results from Training with the Mabinti Tushike Hatamu Out-of-School Girls Program
}

\author{
Population Council \\ in collaboration with \\ Restless Development and UNICEF
}


The Population Council confronts critical health and development issues - from stopping the spread of HIV to improving reproductive health and ensuring that young people lead full and productive lives. Through biomedical, social science, and public health research in 50 countries, we work with our partners to deliver solutions that lead to more effective policies, programs, and technologies that improve lives around the world. Established in 1952 and headquartered in New York, the Council is a nongovernmental, nonprofit organization governed by an international board of trustees.

Population Council

1 Dag Hammarskjold Plaza

New York, NY 10017

USA

Tel: +1 2123390500

Fax: +12127556052

email:pubinfo@popcounil.org

popcouncil.org

Suggested citation:

Kelly Hallman, Ilan Cerna-Turoff and Neema Matee. 2015. "Participatory Research Results from Training with the Mabinti Tushike Hatamu Out-ofSchool Girls Program." New York: Population Council. 


\section{Introduction}

In Tanzania, a Programming Framework for Working with Adolescent Girls was developed by Tanzania AIDS Commission (TACAIDS) in 2012. Under the leadership of TACAIDS, the Mabinti Tushike Hatamu (Girls let's be leaders!) (MTH) project is being implemented by Restless Development (RD) under a program cooperation agreement (PCA) with UNICEF. It is a groundbreaking initiative that is designed to test and evaluate strategies for reducing the vulnerability of out-of-school adolescent girls aged 10-19 years to HIV/AIDS, pregnancy and unfavorable life outcomes in three UNICEF focus regions of the country: Dar es Salaam, Iringa and Mbeya. For the overall MTH project, three wards were purposely-selected in each region based on existing UNICEF program activities. Within each of these nine wards, three villages were randomly selected, for a total of 27 villages. MTH program strategies include:

1. Strengthening individual and group 'agency' among out-of-school females aged 10-19 through peer education, counselling and mentoring, and through establishing Girls Groups (1 per village).

2. Improving understanding within communities and local structures on the added value of investing in girls and the need to foster a protective environment to achieve rights and development.

3. Strengthening linkages with local service providers including schools, health centers, UNICEF child protection units (where they exist), One Stop Centers (where they exist), Police Gender and Children's Desks, and local CBOs to ensure coordination, information sharing, and outreach.

The project design builds on the collective expertise of TACAIDS, UNICEF and RD Tanzania. A report commissioned by TACAIDS on adolescent girls and strategy for HIV prevention, treatment and care was instrumental to the program's design, which is complemented by RD's youth-to-youth peer education and capacity building model.

For the participatory tools training described here, the Population Council was approached by UNICEF and asked to devise a strategy that would enable RD to better capture the richness of its on-going MTH program activities. In response, the Population Council designed a training session and a companion toolkit in participatory action research for the use of MTH girl group leaders ("community volunteers"), aged 19-23 years, to use within their girl groups.

The toolkit includes: (a) community mapping of places girls go and which are safe/unsafe and why; (b) Venn diagramming to explore girls' perceptions of and interactions with community institutions; (c) the social capital game which explores trust, power and connections in girls' lives; and (d) a ranking exercise to unpack the motivations around girls' choices of sexual partners. For each tool, workshop participants were clearly instructed to report on the experiences of a typical local adolescent female who is not enrolled in school, and NOT to report on their own individual experiences. Given the focus group setting of the training and the 
subsequent research, we did not wish to risk a potential breach in confidentiality of any individual's self-reported experiences. Moreover, uncovering the experiences of an average out-of-school adolescent female in each locality was the main objective of the tools and research.

The toolkit was drafted in late 2014; the trainings of the MTH community volunteers took place during April 2015; the toolkit was finalized in June 2015 using experiences from the trainings. The results from randomly selected observations of the community volunteers applying the newly learned tools within their girl groups will be available in late 2015. The toolkit and the research protocol to observe its application were approved by the Tanzania National Institute of Medical Research and by the Population Council's IRB. This report describes the findings from the two trainings with MTH community volunteers that took place in April 2015. It should be noted that although stakeholder participants also applied the tools and presented their results during the workshops, only the MTH community volunteer results are discussed here as they were the main intended targets for the training.

\section{Training locations and participants}

The MTH program is being implemented in UNICEF's priority regions of Dar es Salaam, Iringa and Mbeya. Given this geographic coverage, the trainings were conducted in Dar es Salaam for the Dar community volunteers and in Iringa for the Iringa and Mbeya community volunteers. The Mbeya group traveled to Iringa. In both instances all the community volunteers were lodged together with selected Restless Development staff at a guest lodge/conference facility to encourage social network strengthening and mutual support and learning.

To increase broader knowledge and participation of the community, UNICEF and Restless Development invited local stakeholders to each of the two training sessions. In Dar this consisted of youth/girl program implementers and advocates, as well as national and local government representatives. In Iringa, the stakeholders were mostly local and regional government representatives.

The Dar workshop commenced with a total of 14 stakeholders and six MTH community volunteers (increasing to seven community volunteers on the second day). Three breakout groups were maintained throughout the 2.75 days of training, which included two stakeholder groups and one community volunteer group.

The Iringa training participants consisted of approximately 13 stakeholders and 18 community volunteers (evenly divided between Iringa and Mbeya regions). The facilitators created breakout groups by region for the community volunteers and divided the stakeholders evenly into two groups, for a total of four groups. These breakout groups were maintained for the 2.75 days. 


\section{Methods}

At each workshop, facilitation was shared among Dr. Kelly Hallman, Mr. Ilan Cerna-Turoff (Population Council consultant) and Ms. Neema Matee (Population Council consultant). Restless Development staff participated in the facilitation and translation process in each location: Mr. Omari Abunga in Dar and Mr. Philipo Paul and Ms. Esther Mukasa in Iringa.

Dr. Hallman led introductions to and plenary engagements with each tool, and Mr. Cerna-Turoff facilitated discussions on background topics - good facilitation, participatory methods, and related topics. Ms. Matee, Mr. Abunga, Mr. Paul and Ms. Mukasa supported translation, breakout sessions, and added local flavor to the facilitation process.

During the plenary engagement with each tool, individuals from among the workshop participants were encouraged to help demonstrate its application with Dr. Hallman's guidance. An emphasis was placed on encouraging MTH community volunteers to help first and stakeholders thereafter. Because there were two community volunteer groups in Iringa, assistance with the plenary demonstration of each tool was rotated between the Iringa and Mbeya community volunteers.

In each location, both plenary and break-out sessions were very interactive, and small group report-backs were shared over the three days by various members of the small groups (no one dominated the conversations). Overall, participation was very high amongst both the MTH community volunteers and the stakeholders. Both workshops were rated as highly successful by the participants and the MTH community volunteers showed great enthusiasm in engaging with the tools and with the Population Council facilitators.

\section{Findings from the Dar es Salaam training}

\section{Participatory mapping of local safe and unsafe spaces}

Participatory mapping is a tool in which a map of the community is drawn on a large sheet of paper using colored markers; important places are shown on the map and then labelled as to how often girls go there and whether the place is safe or unsafe for the participants. The MTH community volunteers were very comfortable with this tool. After the demonstration, they needed very little supervision. During the small group breakouts, the community volunteers were first to complete the exercise.

A key finding from the community volunteers' mapping exercise was that when girls involved with MTH's girl groups sought services at the local hospital, they were received well. They reported, however, that other out-of-school adolescent girls were sent away without receiving services, because they did not have the level of confidence, knowledge, and social connections that girls in the MTH groups possessed. 
Two places the volunteers reported that out-of-school adolescent girls frequented but that were rated as rather unsafe (level of 3 on a scale of $0-5$, zero being completely safe) included the video viewing room and a local bar, the George Bush bar. Both places were reported to have many boys and men, along with alcohol at the bar; and although not safe, they were among the few places available to socialize and meet friends in the evening. A local gang area, a barber shop and guest houses were places the volunteers said that out-of-school girls rarely go, largely because of the concentrated presence of unemployed boys and men, some with seemingly less than honorable intentions.

The following table (Table 1) is a translated version of the contents of the community map drawn by the Dar community volunteers; after the table, the volunteers' handwritten version of this table in Kiswahili (Figure 1) and their community map (Figure 2) are presented. The facilitators should have been clearer in instructing the participants to provide reasons for going to the places they considered safe (those rated with zeros in the safety column of Table 1 and Figure 1). This was emphasized in the subsequent training (in Iringa). 
Table 1. Facilitator's recording of map features - Dar es Salaam

Directions: List each place shown on the map, how often girls go to that place, and why they do or do not go to that place.

Location and group type: Dar es Salaam community volunteers

Date: 08 April 2015

\begin{tabular}{|c|c|c|c|c|c|c|}
\hline \multirow[b]{2}{*}{ PLACE } & $\begin{array}{l}\text { Most } \\
\text { times }\end{array}$ & $\begin{array}{l}\text { Some } \\
\text { times }\end{array}$ & Rarely & Never & $\begin{array}{l}\text { Safety of } \\
\text { Space }\end{array}$ & \multirow[b]{2}{*}{$\begin{array}{l}\text { Reasons for going or not going to } \\
\text { this place }\end{array}$} \\
\hline & \multicolumn{4}{|c|}{ (Tick the one that applies) } & $\begin{array}{l}\text { 1-5 Rank } \\
\text { (write } 0 \text { if } \\
\text { it is safe) }\end{array}$ & \\
\hline Video room & $\checkmark$ & & & & 3 & More boys in this area. \\
\hline Industrial area & & & & $\checkmark$ & 5 & Not many people around the area. \\
\hline Shops & $\checkmark$ & & & & 0 & \\
\hline $\begin{array}{l}\text { Village } \\
\text { executive office }\end{array}$ & $\checkmark$ & & & & 0 & \\
\hline $\begin{array}{l}\text { George Bush } \\
\text { bar }\end{array}$ & $\checkmark$ & & & & 3 & More boys and alcohol selling. \\
\hline Bus stand & $\checkmark$ & & & & 0 & \\
\hline $\begin{array}{l}\text { Charcoal selling } \\
\text { store }\end{array}$ & $\checkmark$ & & & & 0 & \\
\hline Pharmacy & $\checkmark$ & & & & 0 & \\
\hline Butchery & & $\checkmark$ & & & 0 & \\
\hline Dispensary & & & $\checkmark$ & & 0 & \\
\hline Mosque & & & $\checkmark$ & & 0 & \\
\hline Residence area & $\checkmark$ & & & & 0 & \\
\hline Gang area & & & $\checkmark$ & & 3 & More unemployed boys and men. \\
\hline Barber shop & & & $\checkmark$ & & 3 & Service providers are men. \\
\hline Guest Houses & & & $\checkmark$ & & 3 & $\begin{array}{l}\text { There are men/boys who go there for } \\
\text { bad reasons like a room for sexual acts. }\end{array}$ \\
\hline
\end{tabular}


Figure 1. Community volunteers' recording of map features - Dar es Salaam

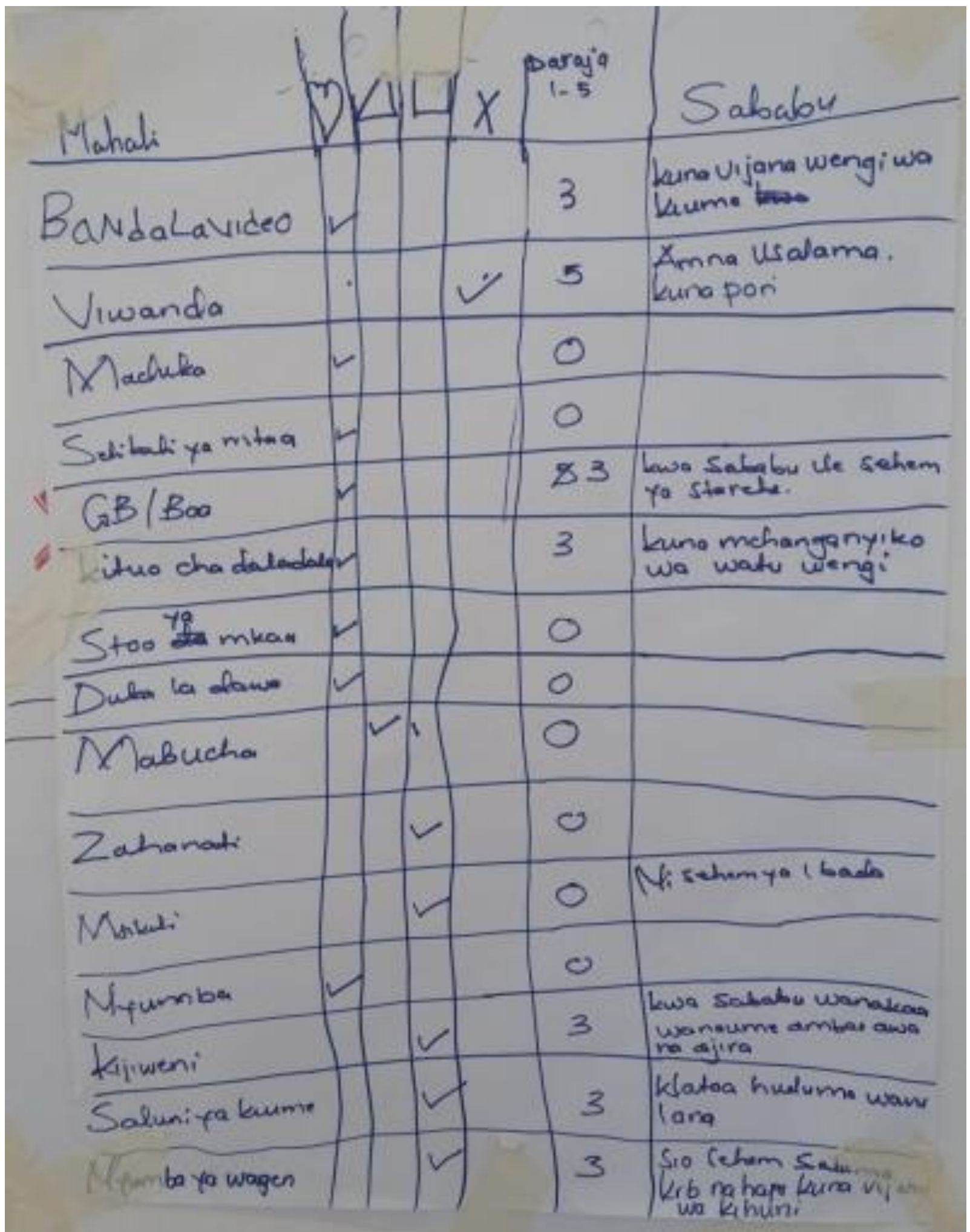

9 
Figure 2. Community volunteers' map - Dar es Salaam

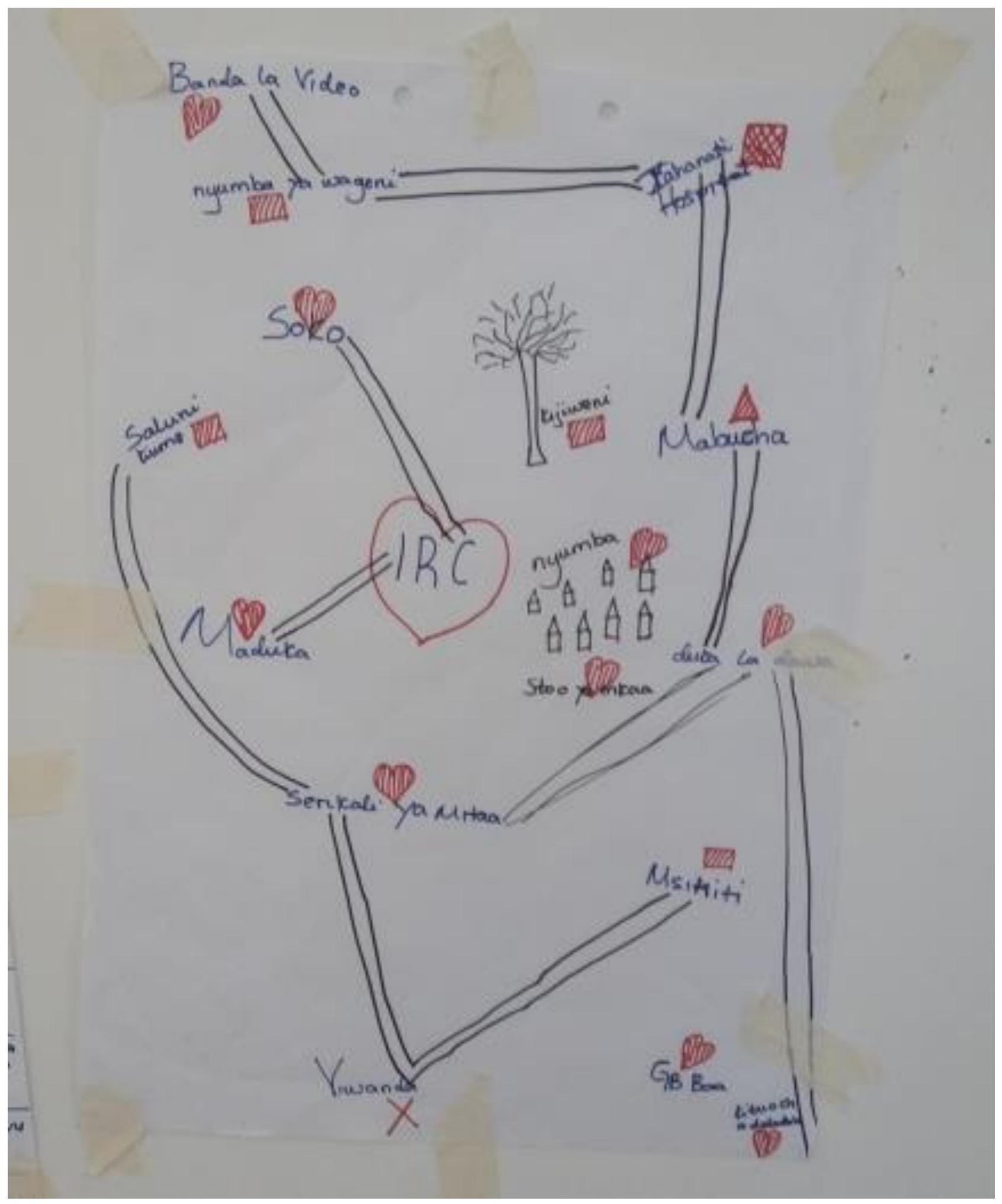


Venn diagram of importance, trust in and links to community institutions

The second tool was a Venn diagram which was used to capture the community volunteers' perceptions of the relative importance, trust in and linkages that out-of-school adolescent girls have with different community institutions. As with the mapping exercise the MTH community volunteers were quick to grasp the purpose of the exercise and applied it well in their small group.

Table 2 is the translated version of the contents of the Dar community volunteers' Venn diagram; followed by their handwritten table in Kiswahili (Figure 3) and then their actual diagram (Figure 4). The diagram produced by the Dar community volunteers revealed that the local government office, the local market, a primary school and a vocational training college were the most important institutions for out-of-school girls. The government office because it has a youth friendly environment and provides advice when the girls need support; the market because girls go there daily to sell goods and procure their needs, even though there is some abuse of girls there (by adult male shopkeepers); the primary school is where girls go daily to sell their goods; the vocational training college provides girls with education such as in tailoring. Institutions that made the list but considered least important included the police, who have a gender desk but are also seen to be corrupt; a local loan group that serves mostly adult women and not many girls; the bank, which serves only a few girls; and a local industry that employs only a handful of girls. The most trusted institutions were the local government office and the vocational college. The community volunteers did not include the MTH groups in their table of Venn diagram features because it was considered their physical and psychic "central institution" (see Figure 4), with all other organizations revolving around the activities of the MTH girl groups. 


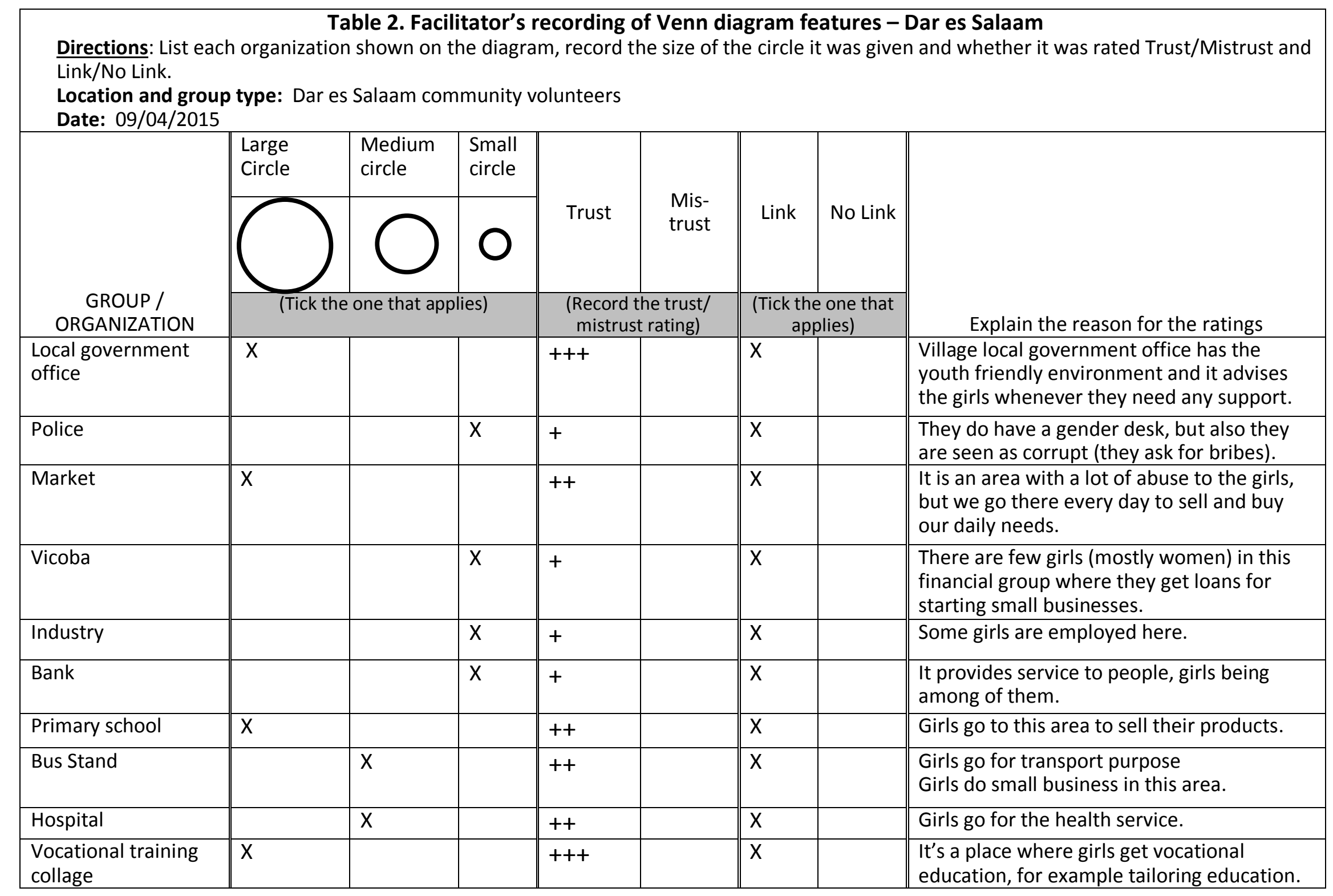


Figure 3. Community volunteers' recording of Venn diagram features - Dar es Salaam

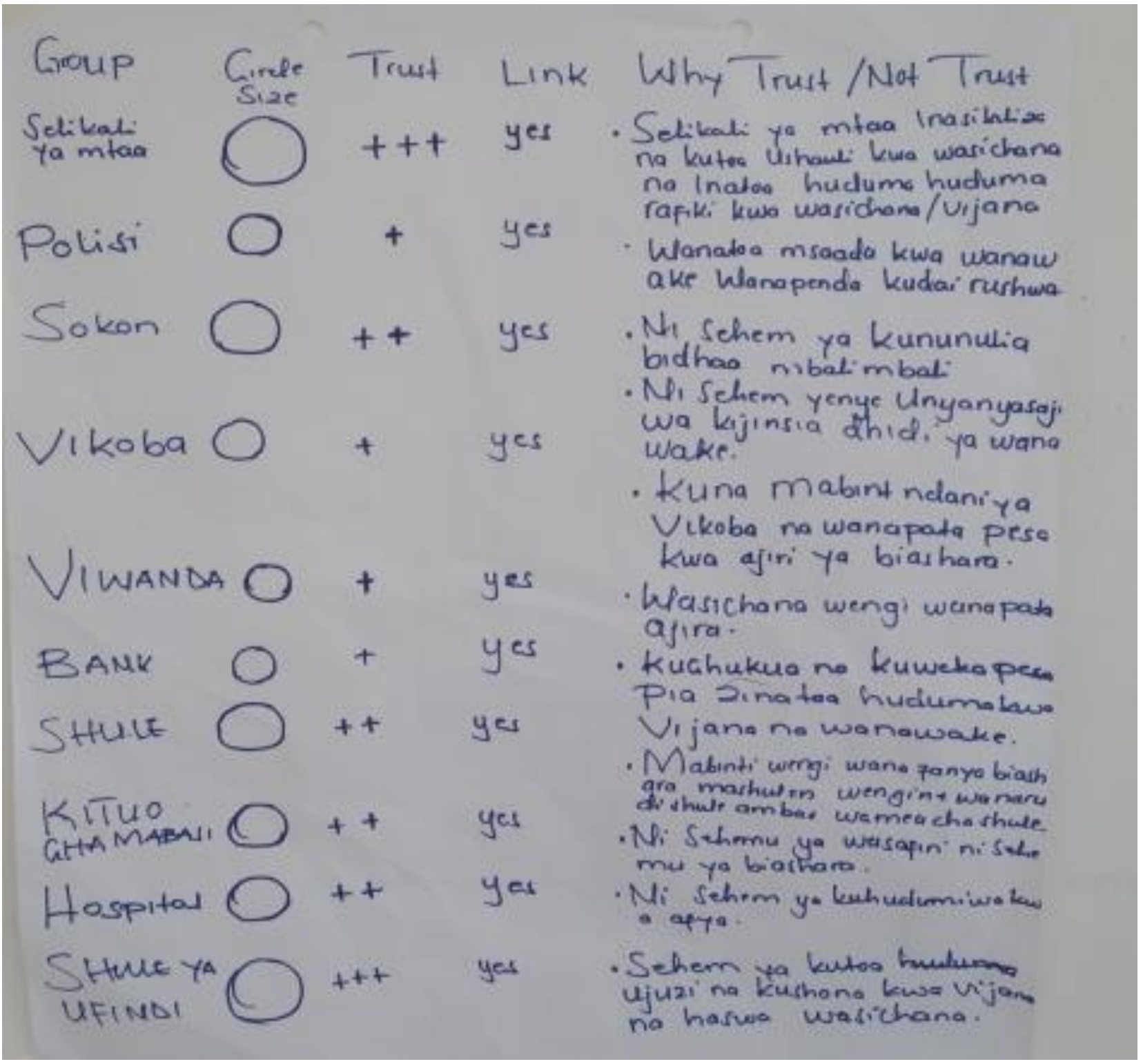




\section{Figure 4. Community volunteers' Venn diagram - Dar es Salaam}

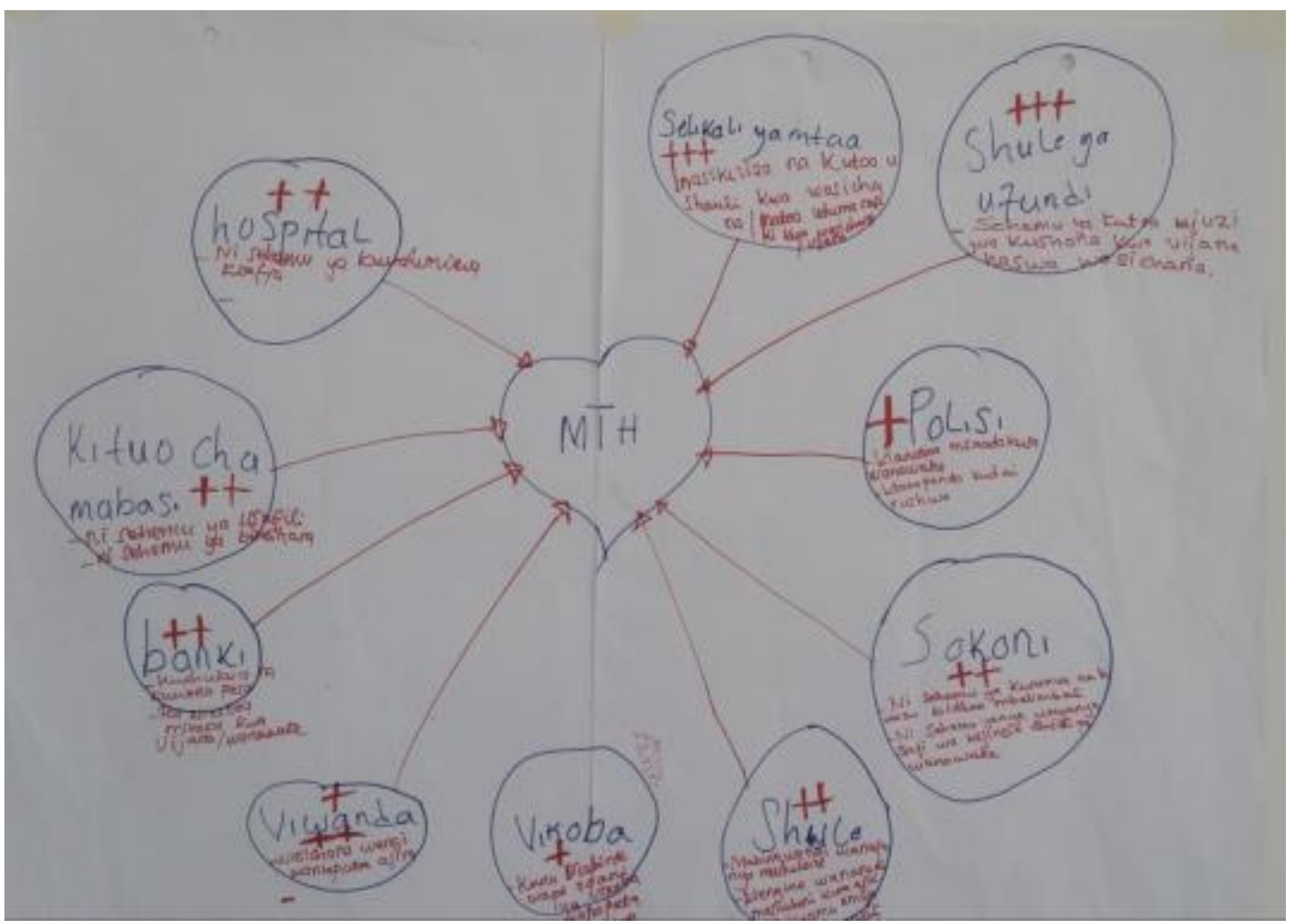


The Social Capital Game of trust, power and connections with individuals in the community

The participants seemed to greatly enjoy the last exercise of the second day-the social capital game, which explores trust, power and connections with various types of local individuals (versus institutions). In this game, the group lists 10 key types of individuals (no proper names) in out-of-school adolescent girls' lives. Participants are then each given a set of cards that signifying trust/no trust, power/no power and link/no link in relation to the 10 listed person types. The participants place their cards next to each of the 10 listed persons of their choice, "spending" their cards on the persons they deem most deserving of each card. Numerous participants spoke about how they would like to use this tool in their communities and to adapt it to other populations. They felt that it was closer to a game than the other exercises and thus, more enjoyable.

Interesting facts that came out of the Dar community volunteers Social Capital Game exercise were that mothers were reported to be by far the most trusted, powerful and close person to out-of-school girls. After mothers, boyfriends were extremely influential, having power and close linkages with out-of-school girls but having a mixed trust rating. Grandmothers tended to live far away from Dar es Salaam in rural areas, so they were reported to not be very involved in the lives of out-of-school girls in the capital city. It was also revealed that neighbors in this urban setting are largely not part of one's life; they have little trust, power or linkages with outof-school girls. Another interesting thread was that both sisters and female friends were reported as not being very trustworthy or powerful, sisters in particular not being able to keep secrets. 
Table 3. Facilitator's recording of social capital game features - Dar es Salaam

Directions: List each key individual from the Social Capital Game and write the total number of cards each receives for each category. Make any notes about that individual in the last column.

Location and group type: Dar es Salaam community volunteers

Date: $09 / 04 / 2015$

\begin{tabular}{|c|c|c|c|c|c|c|c|}
\hline \multirow[b]{2}{*}{ KEY INDIVIDUAL } & \multicolumn{6}{|c|}{ NUMBER OF CARDS } & \multirow[b]{2}{*}{ NOTES ABOUT THE PERSON } \\
\hline & Trust & $\begin{array}{l}\text { No } \\
\text { Trust }\end{array}$ & Power & $\begin{array}{l}\text { No } \\
\text { Power }\end{array}$ & Link & $\begin{array}{l}\text { No } \\
\text { Link }\end{array}$ & \\
\hline MOTHER & 12 & 0 & 7 & 0 & 7 & 0 & $\begin{array}{l}\text { Mothers are so close to a girl child and } \\
\text { they keep secrets. }\end{array}$ \\
\hline FATHER & 1 & 0 & 3 & 0 & 2 & 0 & He is a head of the family. \\
\hline SISTER & 0 & 0 & 0 & 2 & 2 & 0 & $\begin{array}{l}\text { She is a relative but she doesn't keep } \\
\text { secrets. }\end{array}$ \\
\hline BOYFRIEND & 4 & 7 & 7 & 0 & 7 & 0 & $\begin{array}{l}\text { For love relationship and they support } \\
\text { us financially. }\end{array}$ \\
\hline GRANDMOTHER & 1 & 0 & 1 & 0 & 0 & 0 & $\begin{array}{l}\text { We don't live with them, they stay far } \\
\text { from our home but they are involved in } \\
\text { some family issues. }\end{array}$ \\
\hline NEIGHBOUR & 0 & 6 & 0 & 13 & 0 & 9 & $\begin{array}{l}\text { No link as everyone minds his/her } \\
\text { family business/no close relationship, } \\
\text { maybe only during local social } \\
\text { gatherings. }\end{array}$ \\
\hline VILLAGE CHAIRMAN & 0 & 1 & 0 & 0 & 2 & 3 & $\begin{array}{l}\text { For official support only, but cannot } \\
\text { interfere with your personal business. }\end{array}$ \\
\hline A GIRL FRIEND & 0 & 4 & 0 & 3 & 2 & 6 & $\begin{array}{l}\text { We share some secret but she doesn't } \\
\text { have power over me. }\end{array}$ \\
\hline
\end{tabular}


Figure 5. Community volunteers' social capital game results - Dar es Salaam

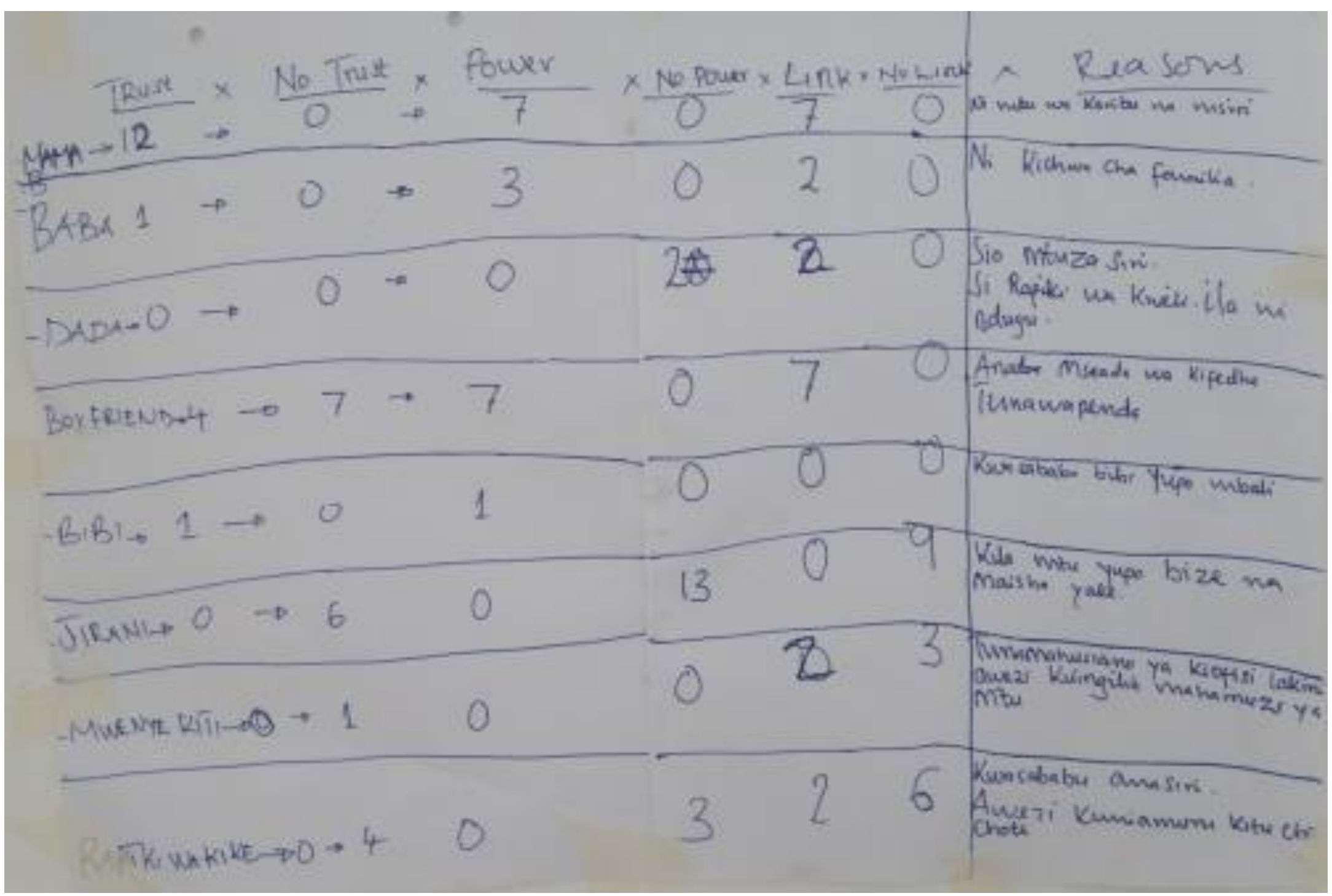




\section{Ranked reasons for having sexual partners of different types}

The ranking exercise was the highlight of the entire workshop. We initially assigned breakout group by different topics (stakeholders focused on alcohol use and risky behaviors, while the community volunteers discussed reasons why out-of-school girls choose various types of sexual partners). We were prepared to do separate report back sessions if the community volunteers felt uncomfortable reporting back on their assigned topic. They decided, however, that they were confident speaking about sexual partners in front of the stakeholders. One young woman, with commentary from the other community volunteers, gave a dynamic, confident presentation on six different types of sexual partners that provide for out-of-school girls' various financial and emotional needs. The adult stakeholders were mesmerized by the detailed information and the number of girls' partners described. As shown in Table 4, each partner type - older men, married men, men who want only sex with no emotional obligations (kibuzi), permanent boyfriend, boy on the side (kidumu - or "gallon"), and the one night stand ("show time/take away") - brings its own distinctive benefits and in some cases obligations.

Older men were described as providing a lot of money, along with parent-like care and no controlling behaviors. Married men were described as easy to have a discreet relationship with; they do not call or ask where you are, largely because they do not want to make or receive calls and therefore risk having their wives find out about the relationship. The men that girls refer to amongst themselves as kibuzi are those who give money and occasional gifts in exchange for sex and do not demand any emotional attachment; they are the men girls meet when they really need money. Kidumu are boys on the side who provide small support like phone vouchers or soda; they are not jealous and understand that girls are free to have other relationships at the same time. "Show time/take away" partners are those with which girls have one night stands and who provide cash only occasionally or on a once-off basis.

Boyfriends were described as age mates that girls could love; individuals that could understand their issues and with whom they could be open and be introduced to the family; and people that they would eventually marry. The nature of this relationship differed greatly from the partners who are older than the girls, who were mostly sources of money. Boyfriends were expected to provide at least some financial support, however. They were also described as being jealous and in some instances controlling of girls' socializing and physical movements about the community. 


\begin{tabular}{|c|c|c|c|c|c|c|}
\hline \multicolumn{7}{|c|}{$\begin{array}{l}\text { Table 4. Facilitator's recording of ranking exercise features - Dar es Salaam } \\
\text { Directions: List each person noted in the Ranking Exercise - order the list so that the person mentioned the first is at the top and the last is at } \\
\text { the bottom of the PERSON TYPE column. Record the reasons girls have sexual relationships with him and write down any other important } \\
\text { notes about that person. } \\
\text { Location and group type: Dar es Salaam community volunteers } \quad \text { Date: } 10 / 04 / 2015\end{array}$} \\
\hline \multirow{2}{*}{$\begin{array}{l}\text { PERSON TYPE } \\
\text { (listed in } \\
\text { order } \\
\text { mentioned) }\end{array}$} & \multicolumn{5}{|c|}{ REASONS FOR HAVING SEXUAL RELATIONSHIP } & \multirow[b]{2}{*}{$\begin{array}{c}\text { NOTES ABOUT THIS } \\
\text { PERSON TYPE }\end{array}$} \\
\hline & Most important & $\begin{array}{l}\text { Second most } \\
\text { important }\end{array}$ & $\begin{array}{l}\text { Third most } \\
\text { important }\end{array}$ & $\begin{array}{l}\text { Fourth most } \\
\text { important }\end{array}$ & $\begin{array}{l}\text { Fifth most } \\
\text { important }\end{array}$ & \\
\hline Older men & $\begin{array}{l}\text { They provide us with a } \\
\text { lot of money. }\end{array}$ & $\begin{array}{l}\text { They are like } \\
\text { parent/they take } \\
\text { care of us. }\end{array}$ & $\begin{array}{l}\text { They don't do follow } \\
\text { up every time. }\end{array}$ & $\begin{array}{l}\text { They bow down on } \\
\text { you/whatever you } \\
\text { say they follow. }\end{array}$ & & $\begin{array}{l}\text { These are very aged } \\
\text { men. }\end{array}$ \\
\hline Married Men & $\begin{array}{l}\text { They keep secret as } \\
\text { they are afraid to be } \\
\text { known by their wives, } \\
\text { which is advantageous } \\
\text { to us. }\end{array}$ & $\begin{array}{l}\text { They are not stress } \\
\text { full, you relax when } \\
\text { dating with this type. }\end{array}$ & $\begin{array}{l}\text { They have respect } \\
\text { over us. }\end{array}$ & $\begin{array}{l}\text { Less control from } \\
\text { them as no } \\
\text { question like } \\
\text { where are you, no } \\
\text { late calls. }\end{array}$ & $\begin{array}{l}\text { They provide } \\
\text { money as a } \\
\text { support. }\end{array}$ & $\begin{array}{l}\text { These are partner } \\
\text { who have family, } \\
\text { wife and kids. }\end{array}$ \\
\hline Kibuzi & They give us money. & $\begin{array}{l}\text { He assists easily } \\
\text { because no } \\
\text { attachment; he } \\
\text { assists in exchange of } \\
\text { sex. }\end{array}$ & $\begin{array}{l}\text { Provide us with } \\
\text { different gifts. }\end{array}$ & $\begin{array}{l}\text { You can go out } \\
\text { with him for } \\
\text { example at the } \\
\text { beach to relax. }\end{array}$ & & $\begin{array}{l}\text { This are the men that } \\
\text { you met only when } \\
\text { you need money }\end{array}$ \\
\hline $\begin{array}{l}\text { Permanent } \\
\text { boyfriend }\end{array}$ & We go for real love. & $\begin{array}{l}\text { We have future } \\
\text { plans. }\end{array}$ & $\begin{array}{l}\text { Easy to go around } \\
\text { with him, and can be } \\
\text { introduced to anyone } \\
\text { anytime. }\end{array}$ & $\begin{array}{l}\text { They are fully of } \\
\text { advice and we } \\
\text { listen. }\end{array}$ & $\begin{array}{l}\text { They have the } \\
\text { childish love, you } \\
\text { can play and } \\
\text { enjoy different } \\
\text { from others. }\end{array}$ & $\begin{array}{l}\text { These are of same } \\
\text { age and can later be } \\
\text { husbands. }\end{array}$ \\
\hline $\begin{array}{l}\text { Kidumu } \\
\text { (gallon) }\end{array}$ & $\begin{array}{l}\text { They provide with small } \\
\text { support for example } \\
\text { telephone credit } \\
\text { voucher or soda when } \\
\text { you are thirsty. }\end{array}$ & $\begin{array}{l}\text { They are not jealous } \\
\text { with you. }\end{array}$ & $\begin{array}{l}\text { You are very free to } \\
\text { have another } \\
\text { relationship and he } \\
\text { won't ask why. }\end{array}$ & & & $\begin{array}{l}\text { These are the side } \\
\text { partner; they go } \\
\text { along with either } \\
\text { permanent boyfriend } \\
\text { or any other. }\end{array}$ \\
\hline $\begin{array}{l}\text { Show } \\
\text { time/take } \\
\text { away }\end{array}$ & $\begin{array}{l}\text { They provide enough } \\
\text { cash in a very short } \\
\text { time. }\end{array}$ & $\begin{array}{l}\text { They are not jealous } \\
\text { as you meet for only } \\
\text { sex purpose once } \\
\text { and everyone leaves. }\end{array}$ & $\begin{array}{l}\text { They don't bother } \\
\text { you with questions, } \\
\text { checking where you } \\
\text { are, who you're with }\end{array}$ & $\begin{array}{l}\text { Having sex is only } \\
\text { once when he } \\
\text { needs you. }\end{array}$ & & $\begin{array}{l}\text { These are the one } \\
\text { night stand men. } \\
\text { More of a business } \\
\text { that just sex. }\end{array}$ \\
\hline
\end{tabular}


Figure 6. Community volunteers' ranking of motivations for sexual partners - Dar es Salaam

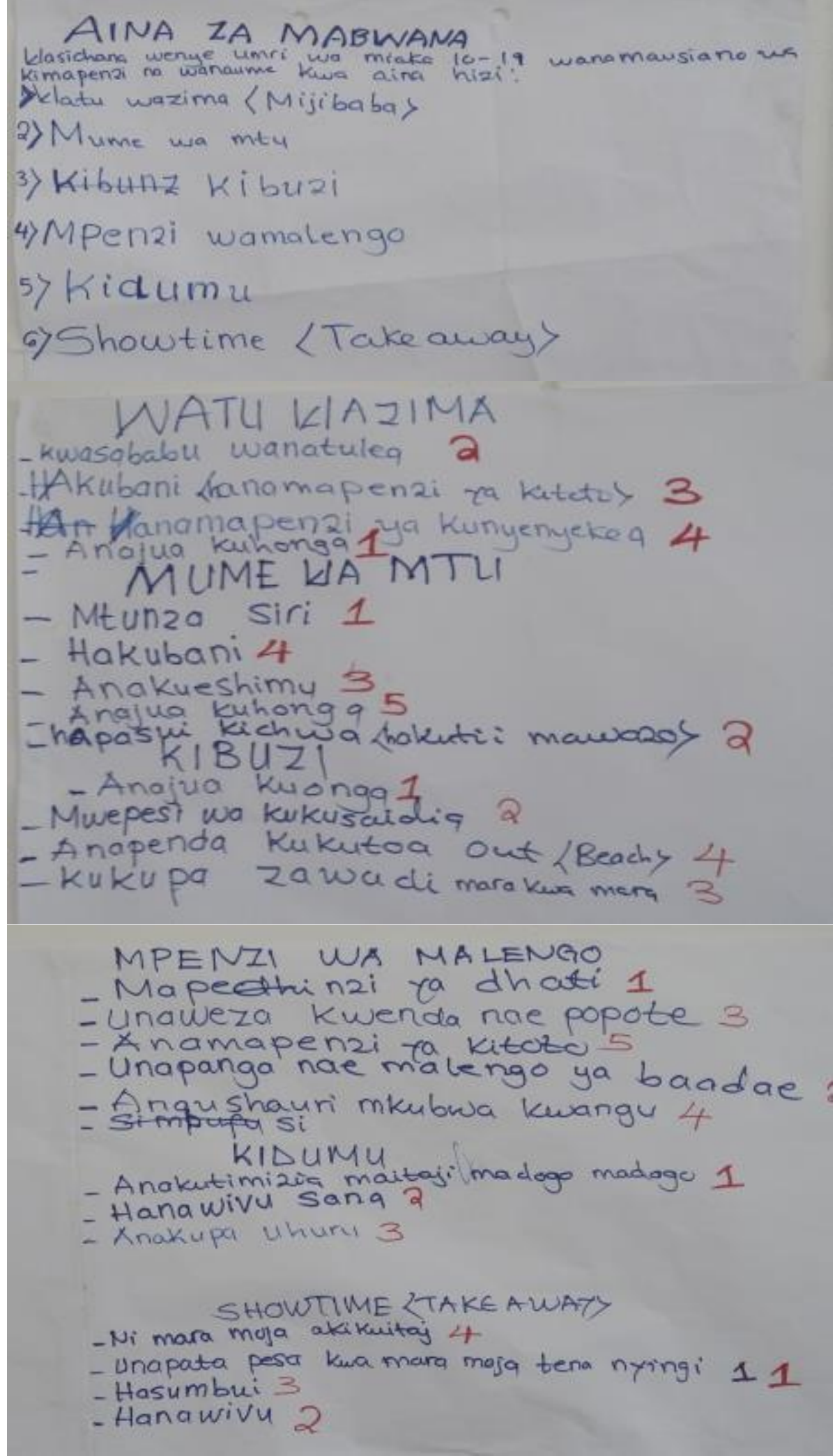




\section{Findings from the Iringa / Mbeya training}

The community volunteers who participated in the demonstration of the first couple tools of the Iringa / Mbeya workshop were much less outgoing than the community volunteers in Dar. They spoke in hushed voices, huddled together when presenting, and took longer to raise their hands or volunteer responses. They started to warm up a bit as the day progressed but were still more shy in presenting in front of a group. This may have been due in part to rural sensibilities and the young women deferring to community elders to show respect. Once the small group sessions started, though, all the workshop participants became more active and in the report back sessions both stakeholders and community volunteers engaged one another by asking many questions about each other's findings. It was difficult to cut off discussions due to keep to the schedule because the groups were enjoying the exercises so much.

Before this training session began, the facilitators were concerned about maintaining participation with the very large group size. Everyone, though, was highly engaged and seemed to genuinely enjoy all three days of the training. Overall, the community volunteers grasped the tools well, took the tasks very seriously and grew in confidence and expressiveness as the workshop proceeded. Many stated that they did not want the workshop to end.

\section{Participatory mapping of local safe and unsafe spaces}

The stakeholders were quite surprised by the young women's mapping results (Table 5 and Figure 7), in particular places in Iringa that were reported by the community volunteers to be frequented by out-of-school girls but had highly unsafe ratings. These were mainly places where girls went in the evenings to socialize and meet people, but which serve alcohol. The young ladies were resolute and informed the stakeholders that girls went to these places to meet friends and these are among the only places available to go in the evening. The only completely safe space described in Iringa was the maktaba, or studying place, followed by the somewhat less safe RUCO/college. 


\section{Table 5. Facilitator's recording of map features - Iringa}

Directions: List each place shown on the map, how often girls go to that place, and why they do or do not go to that place.

Location and group type: Iringa community volunteers

Date: 13/04/2015

\begin{tabular}{|c|c|c|c|c|c|c|}
\hline \multirow[b]{3}{*}{ PLACE } & $\begin{array}{l}\text { Most } \\
\text { time }\end{array}$ & $\begin{array}{l}\text { Some } \\
\text { times }\end{array}$ & Rarely & Never & \multirow{2}{*}{$\begin{array}{l}\text { Safety of } \\
\text { Space }\end{array}$} & \multirow[b]{3}{*}{ Reasons for going or not going this place } \\
\hline & & & & & & \\
\hline & \multicolumn{4}{|c|}{ (Tick the one that applies) } & $\begin{array}{l}\text { 1-5 Rank } \\
\text { (write } 0 \text { if } \\
\text { it is safe) }\end{array}$ & \\
\hline Twisters & $x$ & & & & 5 & $\begin{array}{l}\text { Girls get drunk, possibility of being raped. } \\
\text { Result in early pregnancies. }\end{array}$ \\
\hline $\begin{array}{l}\text { Jiwe } \\
\text { Gangilonga }\end{array}$ & $x$ & & & & 5 & $\begin{array}{l}\text { There are gangs \& criminals; most people } \\
\text { who go there take marijuana. }\end{array}$ \\
\hline Maktaba & $x$ & & & & 0 & Studying place. \\
\hline Club la Pathe & $x$ & & & & 5 & $\begin{array}{l}\text { They sell alcohol; they might get } \\
\text { unplanned pregnancies. }\end{array}$ \\
\hline VIP Club & $x$ & & & & 5 & It a place where they alcohol is sold. \\
\hline $\begin{array}{l}\text { RUCO/ } \\
\text { College }\end{array}$ & & $x$ & & & 1 & $\begin{array}{l}\text { More girls go to this place looking for a } \\
\text { boyfriend; they go to the clubs at night. }\end{array}$ \\
\hline
\end{tabular}


Figure 7. Community volunteers' map and recording of map features - Iringa

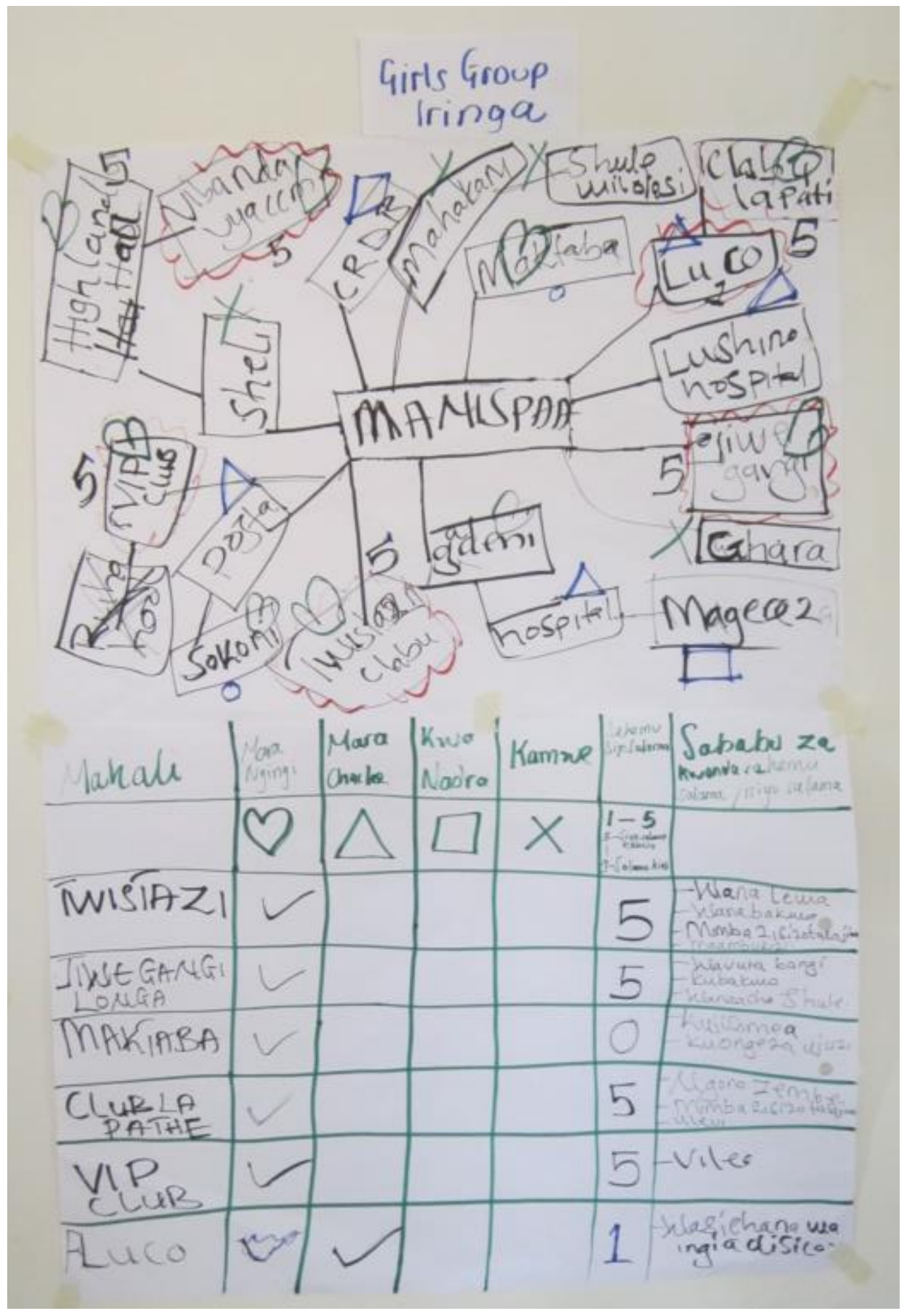


In Mbeya (Table 6 and Figure 8), Sido, the secondhand clothing shop was reported to be a frequented but particularly unsafe place for out-of-school girls, because the shopkeeper wants to trade the clothes in exchange for sex with girls. Residential areas were also areas that were frequented by, but unsafe, for girls who go there to sell small items. Men there attempt to have sex with them in alleys, gardens and behind buildings. Drinking places were not as often visited by girls in Mbeya. There were many more safe spaces reported in Mbeya than in Iringa.

\section{Table 6. Facilitator's recording of map features - Mbeya}

Directions: List each place shown on the map, how often girls go to that place, and why they do or do not go to that place

Location and group type: Mbeya community volunteers

Date: $13 / 04 / 2015$

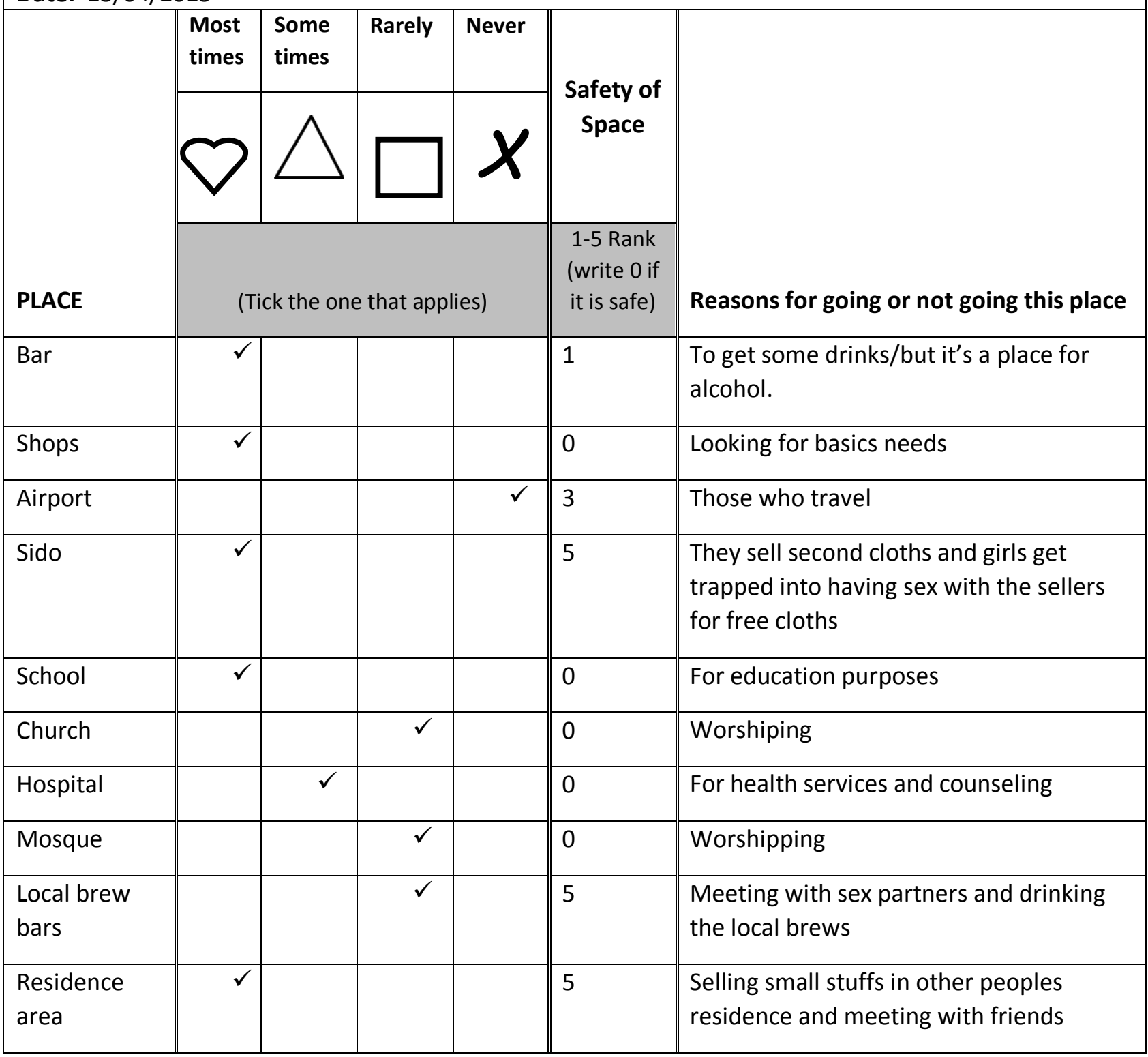


Figure 8. Community volunteers' map and recording of map features - Mbeya

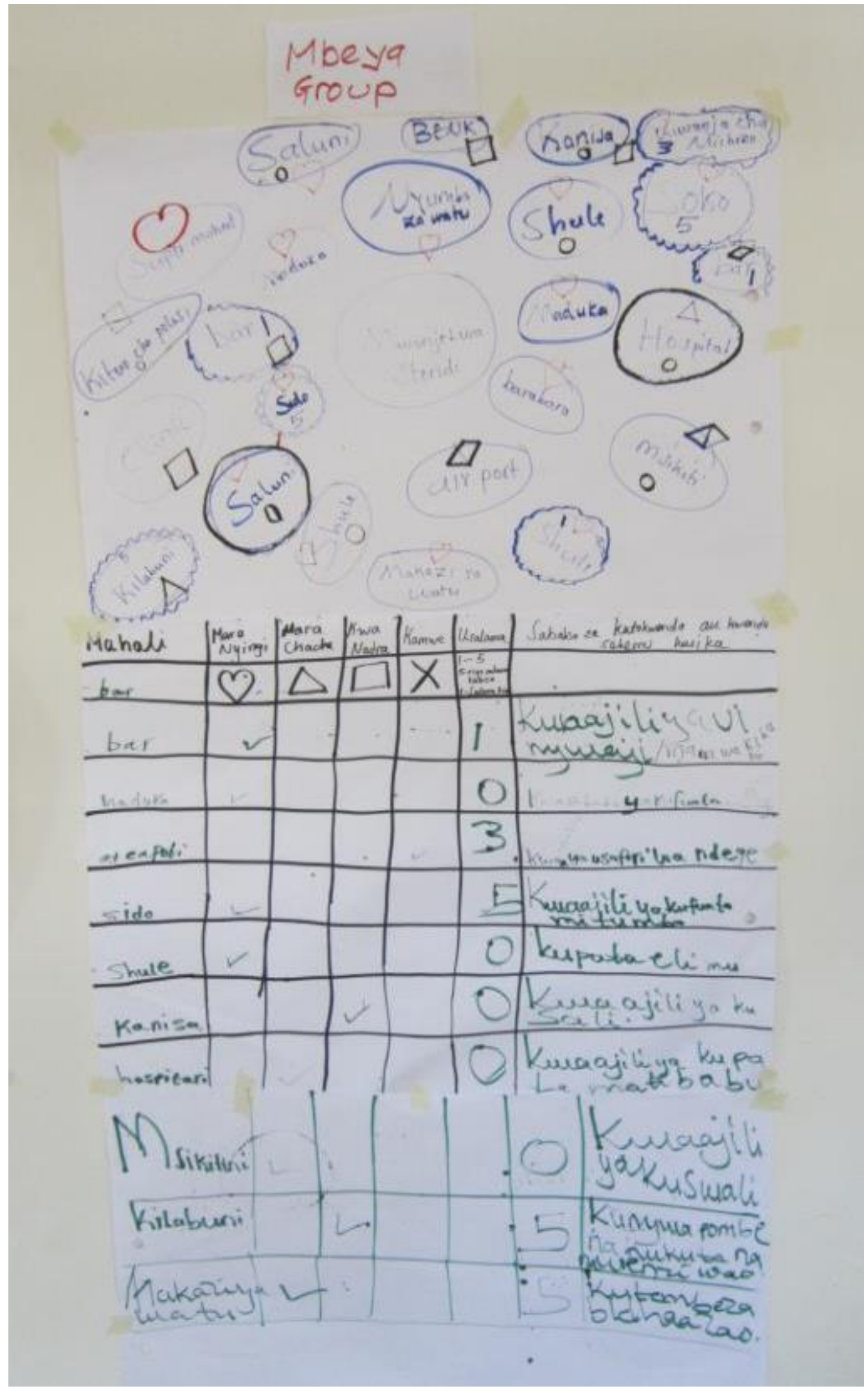


Venn diagram of importance, trust in and links to community institutions

Given their deep engagement with the MTH program, community volunteers from both Iringa and Mbeya (Tables 7 and 8) reported that Restless Development was by far the most important community institution for out-of-school girls. It was also rated as the most (or among the most) trusted by and with close linkages to out-of-school girls. Participants remarked that the MTH program provided girls with confidence, self-esteem and entrepreneurial training, and made them aware of their rights. In Mbeya, one other organization, the KIHUMBE HIV prevention, treatment and care center, was rated equally high in importance, trust and linkages to out-ofschool girls.

In Iringa, the community volunteers reported that out-of-school girls had linkages with two organizations that were rated as medium in importance and trust: Mtoto Salama, an HIV support organization, and the Coradini Mission, which provides girls with entrepreneurial education. Organizations that made the list for Iringa but considered of low importance to outof-school girls included the Neema social support group, the Watukutu Camp, and the Wakali sisi dance group for boys; none of these included girls (whether in- or out-of-school) in their programming. (It should be noted that the young women's diagrams indicate that they did not use the "mistrust" column of the table and simply indicated trust in institutions by using 1,2 , or 3 plus signs in the "trust" column.)

In Mbeya two organizations with medium importance and trust levels were the SHIDEPHA HIV prevention organization and the Tanzania Social Action Fund (TASAF). A linkage was reported with the former, but not the latter. In Mbeya, three microfinance groups were given low importance, trust and linkage ratings because they served only older women and not young women/girls. An overall observation from the Venn diagram results was that in Mbeya, all of the institutions mentioned, except for Restless Development, were local, mutual aid society structures. NGOs appeared to have much less of an influence on out-of-school girls' lives in that region than in Iringa. 


\begin{tabular}{|c|c|c|c|c|c|c|c|c|}
\hline \multicolumn{9}{|c|}{$\begin{array}{l}\text { Table 7. Facilitator's recording of venn diagram features - Iringa } \\
\text { Directions: List each organization shown on the diagram, record the size of the circle, whether it was rated Trust/Mistrust and } \\
\text { Link/No Link. } \\
\text { Location and group type: Iringa community volunteers } \\
\text { Date: } 14 / 04 / 2015\end{array}$} \\
\hline \multirow[b]{2}{*}{$\begin{array}{c}\text { GROUP / } \\
\text { ORGANIZATION }\end{array}$} & $\begin{array}{l}\text { Large } \\
\text { Circle }\end{array}$ & $\begin{array}{l}\text { Medium } \\
\text { circle }\end{array}$ & $\begin{array}{l}\text { Small } \\
\text { circle }\end{array}$ & Trust & $\begin{array}{l}\text { Mis- } \\
\text { trust }\end{array}$ & Link & $\begin{array}{l}\text { No } \\
\text { Link }\end{array}$ & \multirow[b]{2}{*}{ Explain the reason for the ratings } \\
\hline & \multicolumn{3}{|c|}{ (Tick the one that applies) } & \multicolumn{2}{|c|}{$\begin{array}{l}\text { (Tick the one that } \\
\text { applies) }\end{array}$} & \multicolumn{2}{|c|}{$\begin{array}{l}\text { (Tick the one } \\
\text { that applies) }\end{array}$} & \\
\hline $\begin{array}{l}\text { Restless } \\
\text { Development }\end{array}$ & $X$ & & & +++ & & $x$ & & $\begin{array}{l}\text { Make girls aware of their rights and } \\
\text { gave the confidence to stand on. }\end{array}$ \\
\hline $\begin{array}{l}\text { Mtoto Salama } \\
\text { group }\end{array}$ & & $X$ & & ++ & & $x$ & & $\begin{array}{l}\text { It deals with stigma in the community; } \\
\text { it also supports girls who are living with } \\
\text { HIV. }\end{array}$ \\
\hline Coradini Mission & & $X$ & & ++ & & $x$ & & $\begin{array}{l}\text { It provides entrepreneur education to } \\
\text { the girls. }\end{array}$ \\
\hline Neema group & & & $x$ & + & & $x$ & & It a social support group. \\
\hline Watukutu Camp & & & $x$ & & & & $x$ & $\begin{array}{l}\text { Girls are not involved in this group its } \\
\text { only boys. }\end{array}$ \\
\hline Wakali sisi Camp & & & $x$ & + & & $\mathrm{x}$ & & $\begin{array}{l}\text { Few girls are participating in dancing } \\
\text { group so they get money. }\end{array}$ \\
\hline
\end{tabular}




\section{Figure 9. Community volunteers' Venn diagram - Iringa}

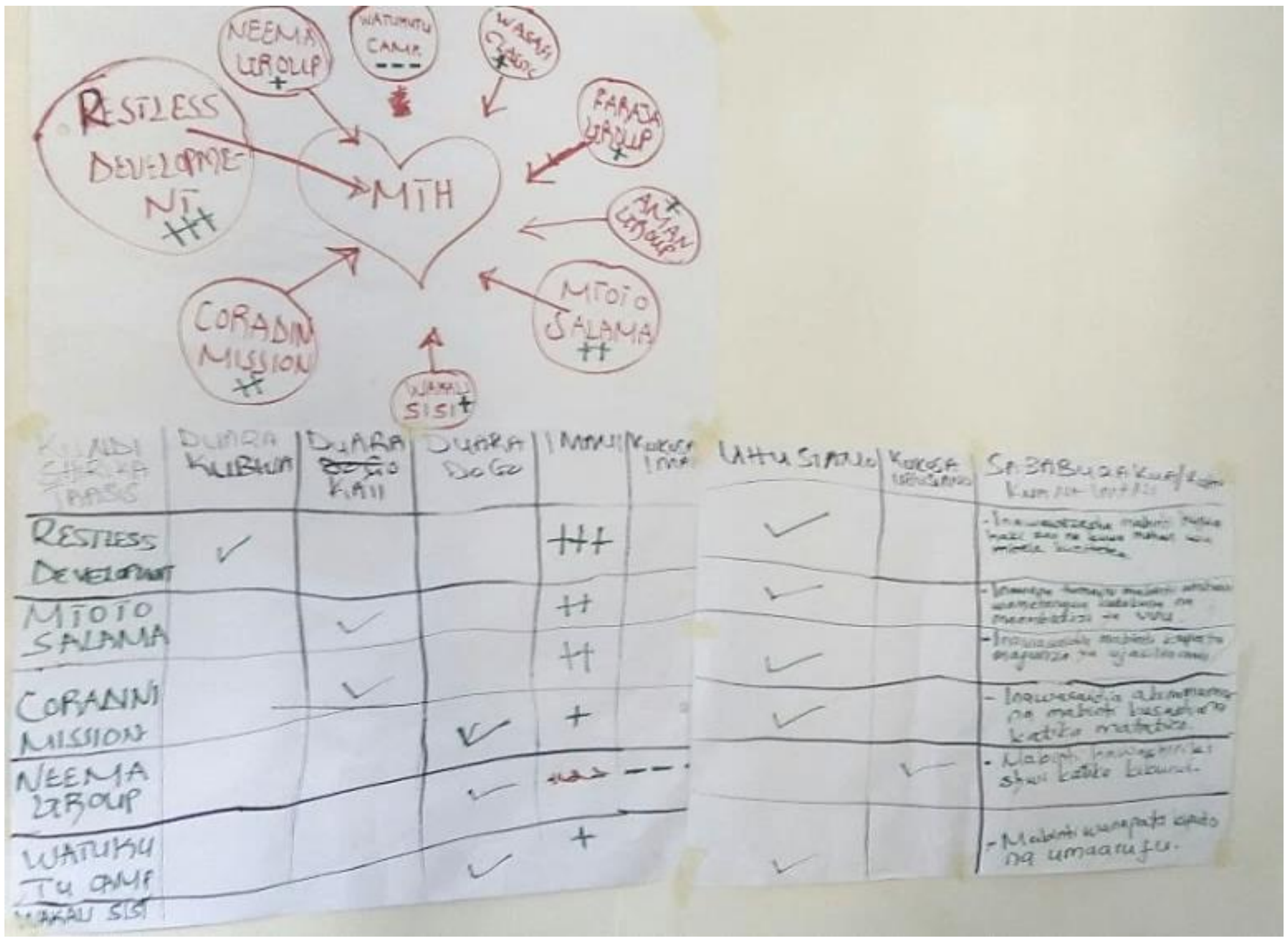




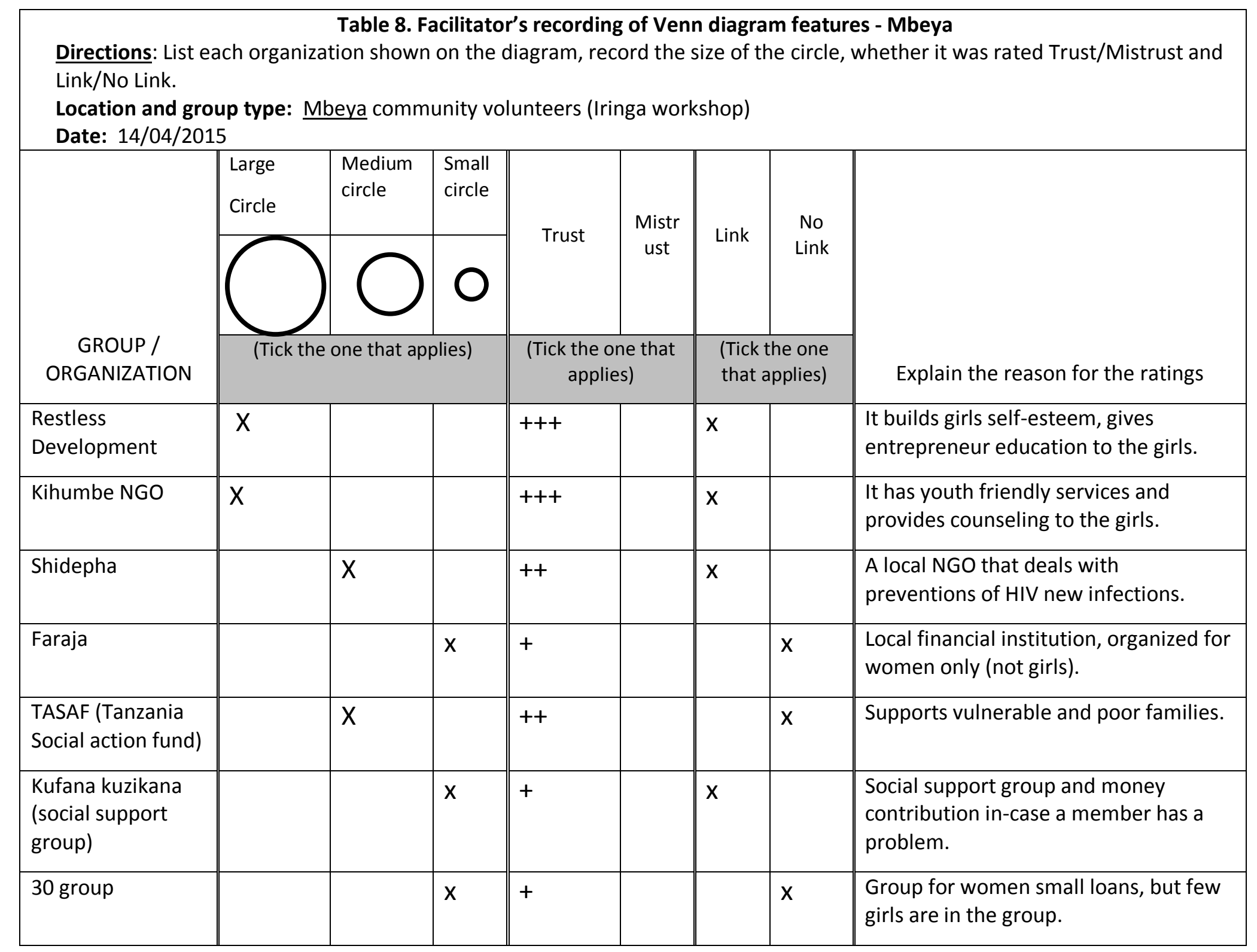


Figure 10. Community volunteers' Venn diagram - Mbeya

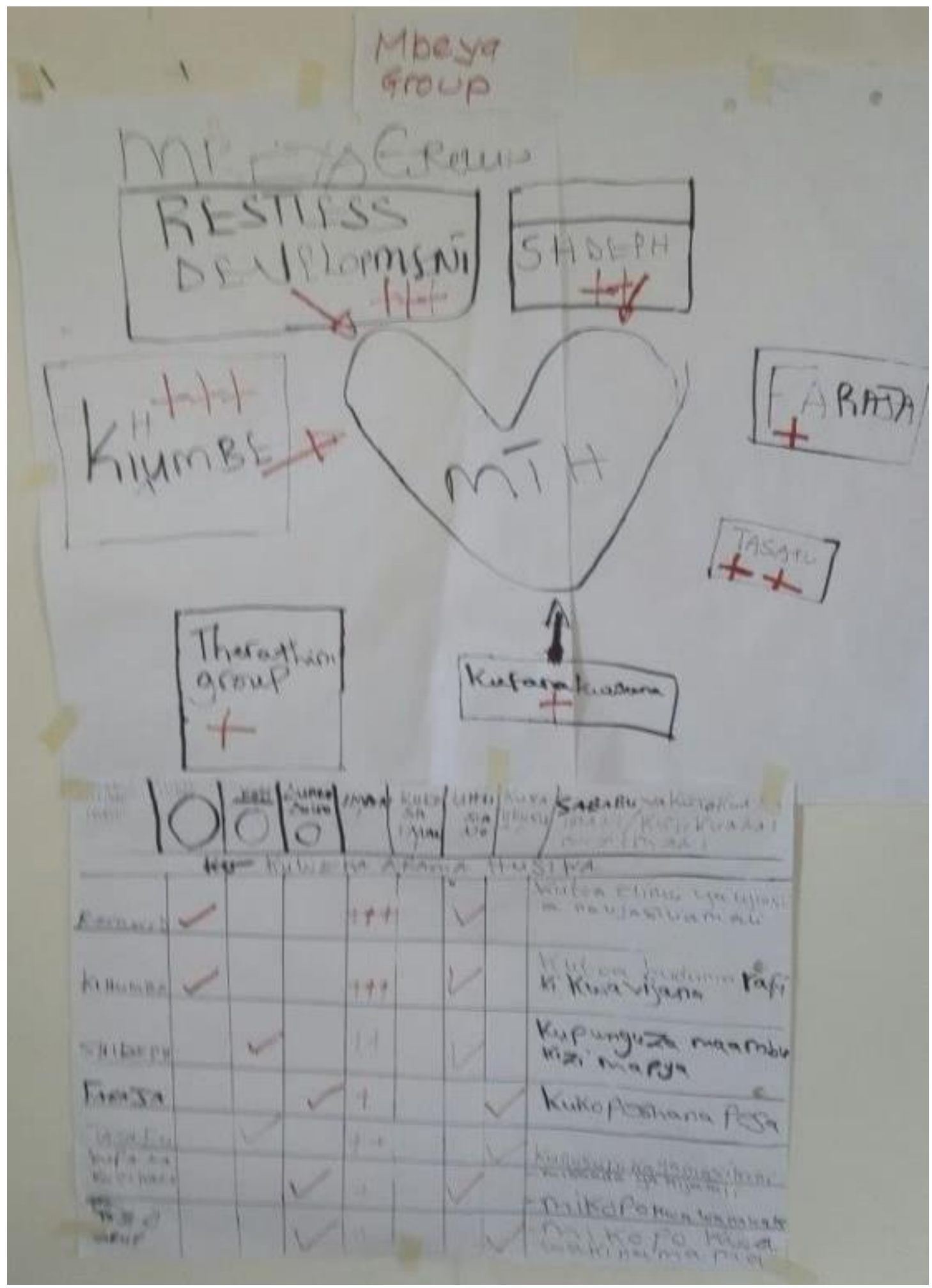


The Social Capital Game of trust, power and connections with individuals in the community

During the afternoon of Day 2 the Social Capital Game was introduced in plenary with the assistance of the Iringa community volunteers. This was followed by small break out groups which undertook the game themselves. By this time both groups of community volunteers were more active and relaxed than on Day 1.

Near the end of Day 2, the facilitators inquired in a confidential manner with the community volunteer groups about whether they would feel comfortable speaking openly in front of the local stakeholders about the sexual relationships that out-of-school girls have. They stated that they would not be able to be completely truthful in the presence of the stakeholders. In dialogue with Ms. Mukasa, a plan was therefore made to release the stakeholders early on Day 3 after the report-back on the Social Capital Game was finished. The community volunteers were to remain from $11 \mathrm{am}$ to $3 \mathrm{pm}$ to train them in last tool, the Ranking Exercise, and have lunch. The announcement of this change in plans clearly pleased the stakeholders and set the community volunteers more at ease.

On Day 3, all the small groups presented their results of the Social Capital Game. Dynamics had clearly shifted since Day 1 . Whereas, the community volunteers had been shy and reserved previously, both groups spoke their minds bluntly about issues in their community and spoke with confidence in plenary about different types of people in the community who did not respect girls. The young women were very brave and straightforward in their descriptions.

While mothers remained among the most important individuals for adolescent out-of-school girls, in the rural areas fathers were reported to play as prominent a role (Tables 9 and 10). This is likely due to differing household structures in the rural versus urban setting. Among the three sites, fathers in Iringa received a high number of trust, power and linkage cards in the community volunteers' game. Father's sisters and grandmothers were among the individuals listed in the exercise but reported to not have a large influence on rural out-of-school girls' lives.

On a more negative note, shopkeepers, local government councilors and veterinary officers in Iringa received highly unfavorable ratings from the community volunteers, but each for different reasons. Shopkeepers had to be dealt with but were disrespectful to out-of-school girls; the local government councilor needs to be consulted for girl group matters but are not always helpful; veterinary officers were reported to want to have sex with out-of-school girls.

The Mbeya community volunteer group mentioned that out-of-school girls were often sexually harassed and/or violated by both male teachers and religious leaders. Being out-of-school was reported to only intensify the problem, because teachers no longer saw any conflict in impregnating the girls once they had dropped out of school. Nurses were mentioned here (perhaps because of the higher HIV burden) and were somewhat trusted but reported to be too busy and overworked to devote much time to the out-of-school girls who sought care. Village executive officers were reported to have some power over girls but were not highly trusted. 
Table 9. Facilitator's recording of social capital game features - Iringa

Directions: List each key individual from the Social Capital Game and write the total number of cards they receive for each category. Make any notes about that individual in the last column.

Location and group: Iringa community volunteers

Date: $14 / 04 / 2015$

\begin{tabular}{|c|c|c|c|c|c|c|c|}
\hline \multirow[b]{2}{*}{ KEY INDIVIDUAL } & \multicolumn{6}{|c|}{ NUMBER OF CARDS } & \multirow[b]{2}{*}{ NOTES ABOUT THE PERSON } \\
\hline & Trust & $\begin{array}{l}\text { No } \\
\text { Trust }\end{array}$ & Power & $\begin{array}{c}\text { No } \\
\text { Power }\end{array}$ & Link & $\begin{array}{c}\text { No } \\
\text { Link }\end{array}$ & \\
\hline Mother & 3 & 0 & 6 & 0 & 9 & 0 & $\begin{array}{l}\text { Mothers are so close to a girl and are the } \\
\text { family advisors }\end{array}$ \\
\hline Father & 5 & 0 & 10 & 0 & 6 & 0 & $\begin{array}{l}\text { He is a head of the family. } \\
\text { He supports the family financially. }\end{array}$ \\
\hline Aunt (father's sister) & 0 & 3 & 0 & 0 & 0 & 0 & They don't keep secrets. \\
\hline Female friend & 0 & 1 & 0 & 3 & 3 & 0 & $\begin{array}{l}\text { They don't have good advice, they might } \\
\text { tell you to run away from home in case } \\
\text { you express any problem in your home. }\end{array}$ \\
\hline Mangi (shopkeeper) & 0 & 6 & 0 & 7 & 0 & 5 & $\begin{array}{l}\text { They give us stuff for credits but they } \\
\text { don't have a polite language. }\end{array}$ \\
\hline Uncle (mother's brother) & 0 & 1 & 0 & 0 & 0 & 3 & They don't support us. \\
\hline $\begin{array}{l}\text { Councilor (local government } \\
\text { leader) }\end{array}$ & 0 & 3 & 1 & 4 & 0 & 3 & $\begin{array}{l}\text { This is a government leader we consult } \\
\text { them in some issues but they don't have } \\
\text { control over the girls. }\end{array}$ \\
\hline Veterinary officer & 0 & 4 & 1 & 4 & 0 & 7 & They want sex with the girls. \\
\hline
\end{tabular}


Figure 11. Community volunteers' social capital game results - Iringa

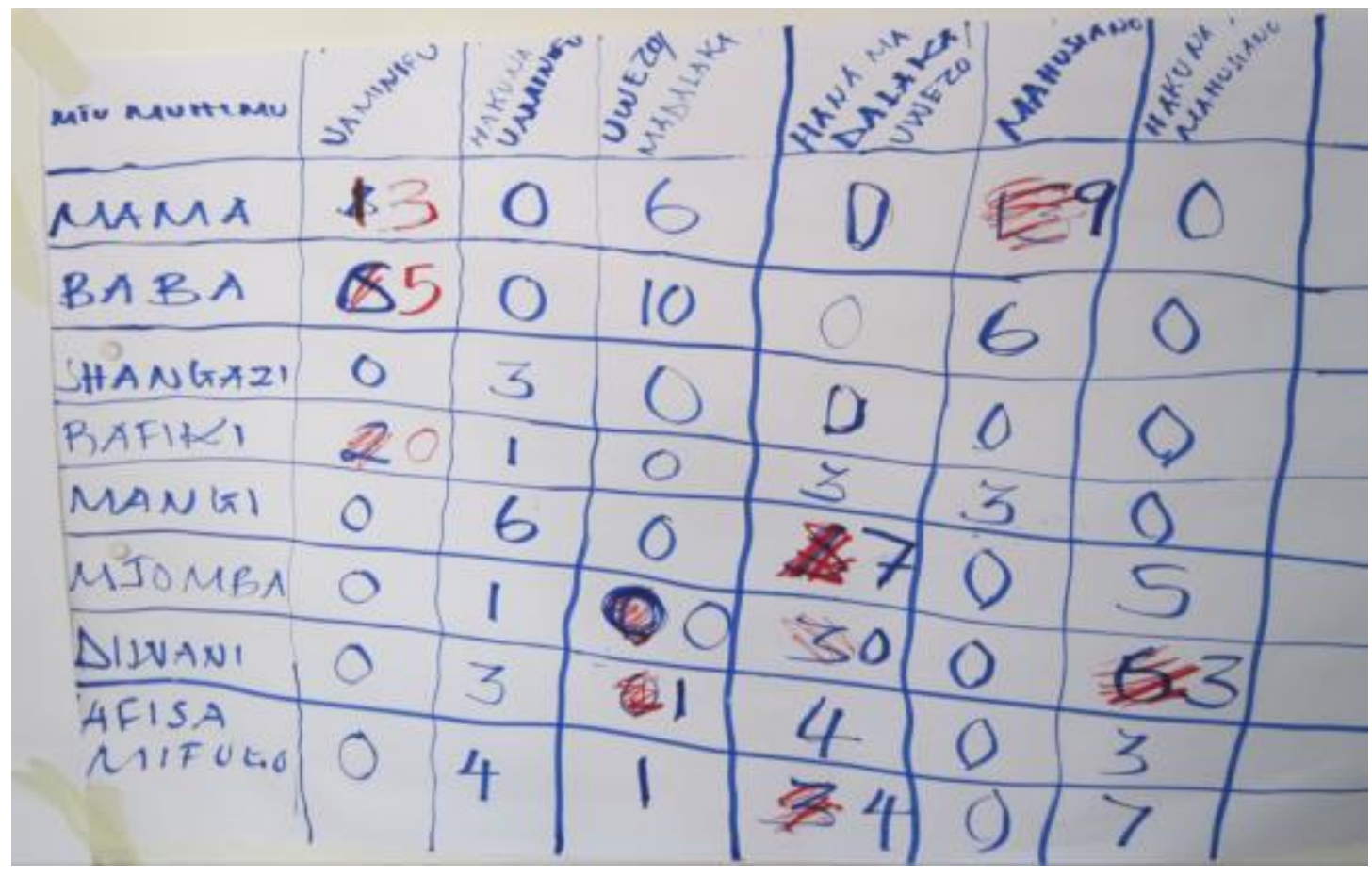




\section{Table 10. Facilitator's recording of social capital game features - Mbeya}

Directions: List each key individual from the Social Capital Game and write the total number of cards they receive for each category. Make any notes about that individual in the last column.

Location and group type: Mbeya community volunteers (Iringa workshop)

Date: 14/04/2015

\begin{tabular}{|c|c|c|c|c|c|c|c|}
\hline \multirow[b]{2}{*}{ KEY INDIVIDUAL } & \multicolumn{6}{|c|}{ NUMBER OF CARDS } & \multirow[b]{2}{*}{ NOTES ABOUT THE PERSON } \\
\hline & Trust & $\begin{array}{l}\text { No } \\
\text { Trust }\end{array}$ & Power & $\begin{array}{l}\text { No } \\
\text { Power }\end{array}$ & Link & $\begin{array}{l}\text { No } \\
\text { Link }\end{array}$ & \\
\hline Mother & 7 & 0 & 3 & 0 & 9 & 3 & She takes care of the family \\
\hline Father & 3 & 4 & 7 & 0 & 3 & 2 & $\mathrm{He}$ is a head of the family \\
\hline Nurse & 2 & 0 & 2 & 2 & 1 & 1 & $\begin{array}{l}\text { They are too busy and they are few in } \\
\text { the } \mathrm{HC} \text { so we don't get supports as girls }\end{array}$ \\
\hline Grandmother & 3 & 2 & 0 & 8 & 3 & 0 & $\begin{array}{l}\text { They don't provide us with anything } \\
\text { and they are old. }\end{array}$ \\
\hline Teacher & 0 & 3 & 1 & 6 & 1 & 3 & $\begin{array}{l}\text { They ask for sexual relationship to } \\
\text { students and girls out of school. }\end{array}$ \\
\hline Village executive officer & 0 & 3 & 5 & 0 & 1 & 0 & $\begin{array}{l}\text { They are supporting girls group and its } \\
\text { activities. }\end{array}$ \\
\hline Pastor/Padre (Christian leaders) & 2 & 5 & 0 & 1 & 0 & 5 & $\begin{array}{l}\text { We don't trust them as they ask for sex } \\
\text { to the girls. }\end{array}$ \\
\hline Sheik (Islamic leaders) & 1 & 1 & 0 & 1 & 0 & 4 & $\begin{array}{l}\text { Girls don't trust them because they } \\
\text { have sexual relationship with younger } \\
\text { girls. }\end{array}$ \\
\hline
\end{tabular}


Figure 12. Community volunteers' social capital game results - Mbeya

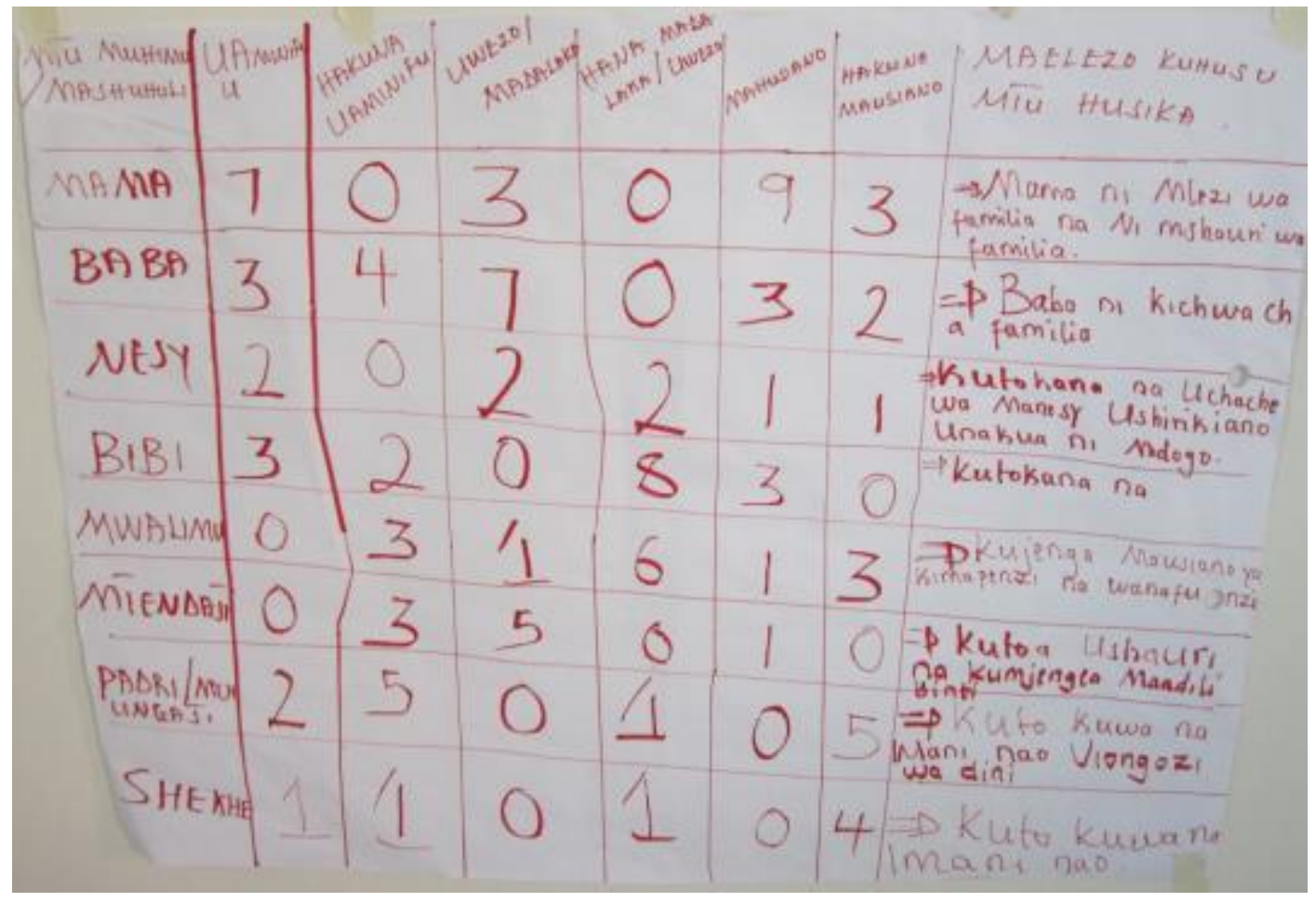




\section{$\underline{\text { Ranked reasons for having sexual partners of different types }}$}

After the stakeholders left the workshop at mid-morning on Day 3, the community volunteers remained to learn the Ranking Exercise. The departure of the stakeholders completely changed the demeanor of community volunteers and they became much more outgoing and expressive.

The types and motivations for sexual partnerships described by both rural groups (Tables 11 and 12) overlapped to a large extent with those described by the young women in Dar with several notable exceptions.

Married men, very old men, kidumu (gallon, or side partner), a man you meet only for sex when you need money, and boyfriend were all mentioned in the urban and rural settings and the motivations for partnering with each were similar across the three regions. The one night stand ("show time/take away") described in Dar and Iringa but not Mbeya.

Not mentioned in Dar but listed by both the Iringa and Mbeya community volunteers was the category of masharobaro - or show off boys. These are young men who do not work, dress and groom themselves neatly, change clothes several times per day, and are desirable for girls to be seen with in the community.

In Iringa, the community volunteers also described classmates as sexual partners to adolescent girls. It was unclear whether the girls referred to were enrolled in formal school or entrepreneurial/vocational training programs. These young men were reported to assist girls academically and to provide small gifts like snacks at school.

Two partner types that were unique to the Mbeya group's list were drivers and "bosses". Drivers were reported as prominent sexual partners for out-of-school girls in Mbeya because rural transport is such a large challenge and drivers provide lifts in exchange for sex. Bosses were described as men who are in the formal workforce and provide girls with a chance for employment, money when girls need it, and social prestige when others see them together in the community. 


\begin{tabular}{|c|c|c|c|c|c|c|}
\hline \multicolumn{7}{|c|}{$\begin{array}{l}\text { Table 11. Facilitator's recording of ranking exercise features - Iringa } \\
\text { Directions: List each person noted in the Ranking Exercise - order the list so that the person mentioned the first is at the top and the last is at } \\
\text { the bottom of the PERSON TYPE column. Record the reasons girls have sexual relationships with him and write down any other important } \\
\text { notes about that person. } \\
\text { Location and group type: Iringa community volunteers } \\
\text { Date: } 15 / 04 / 2015\end{array}$} \\
\hline \multirow[b]{2}{*}{$\begin{array}{l}\text { PERSON TYPE } \\
\text { (listed in order } \\
\text { mentioned) }\end{array}$} & \multicolumn{5}{|c|}{\begin{tabular}{|l} 
REASONS FOR HAVING SEXUAL RELATIONSHIP \\
\end{tabular}} & \multirow[b]{2}{*}{$\begin{array}{l}\text { NOTES ABOUT } \\
\text { THIS PERSON } \\
\text { TYPE }\end{array}$} \\
\hline & Most important & $\begin{array}{l}\text { Second most } \\
\text { important }\end{array}$ & $\begin{array}{l}\text { Third most } \\
\text { important }\end{array}$ & $\begin{array}{l}\text { Fourth most } \\
\text { important }\end{array}$ & $\begin{array}{l}\text { Fifth most } \\
\text { important }\end{array}$ & \\
\hline Married men & $\begin{array}{l}\text { They don't have a tight } \\
\text { schedule with you so } \\
\text { you get time to have } \\
\text { another partner }\end{array}$ & $\begin{array}{l}\text { They are not } \\
\text { jealous, they cope } \\
\text { easy with the } \\
\text { environment }\end{array}$ & & & & $\begin{array}{l}\text { This person has } \\
\text { families besides the } \\
\text { girls }\end{array}$ \\
\hline Masharobaro & $\begin{array}{l}\text { It easy and proud to } \\
\text { hang out with them }\end{array}$ & $\begin{array}{l}\text { They are there for } \\
\text { outings as they are } \\
\text { so smart and good } \\
\text { looking boys. }\end{array}$ & $\begin{array}{l}\text { They are neat from } \\
\text { morning to } \\
\text { evening. }\end{array}$ & & & $\begin{array}{l}\text { These are the neat } \\
\text { boys where they } \\
\text { can change clothing }\end{array}$ \\
\hline $\begin{array}{l}\text { Older people } \\
\text { (fataki) }\end{array}$ & $\begin{array}{l}\text { They are so supportive } \\
\text { in terms of money, } \\
\text { cloth, school fees etc. }\end{array}$ & $\begin{array}{l}\text { They pay a house } \\
\text { rent for you. }\end{array}$ & $\begin{array}{l}\text { They are so caring } \\
\text { even the way they } \\
\text { talk to you. }\end{array}$ & & & $\begin{array}{l}\text { These are the aged } \\
\text { men, who like to } \\
\text { have sex with } \\
\text { younger girls }\end{array}$ \\
\hline $\begin{array}{l}\text { Classmate (kidato } \\
\text { kimoja) }\end{array}$ & $\begin{array}{l}\text { They assist you } \\
\text { academically }\end{array}$ & $\begin{array}{l}\text { Buy us small stuff } \\
\text { like snacks when we } \\
\text { are in school. }\end{array}$ & $\begin{array}{l}\text { You go to club with } \\
\text { them. }\end{array}$ & & & $\begin{array}{l}\text { These are } \\
\text { classmates but } \\
\text { there is a sexual } \\
\text { relationship too }\end{array}$ \\
\hline Short time & Fast money & No attachment & & & & $\begin{array}{l}\text { These are } \\
\text { completely for } \\
\text { having sex, no other } \\
\text { attachment }\end{array}$ \\
\hline Boyfriend & For real love & $\begin{array}{l}\text { There is future plans } \\
\text { like getting married }\end{array}$ & $\begin{array}{l}\text { For exchanging } \\
\text { ideas }\end{array}$ & $\begin{array}{l}\text { You can share } \\
\text { problem and he } \\
\text { can advice, and we } \\
\text { respond to their } \\
\text { advice. }\end{array}$ & & $\begin{array}{l}\text { These are the } \\
\text { permanent } \\
\text { boyfriend where } \\
\text { you can introduce } \\
\text { them at home }\end{array}$ \\
\hline
\end{tabular}


Figure 13. Community volunteers' ranking of motivations for sexual partners - Iringa

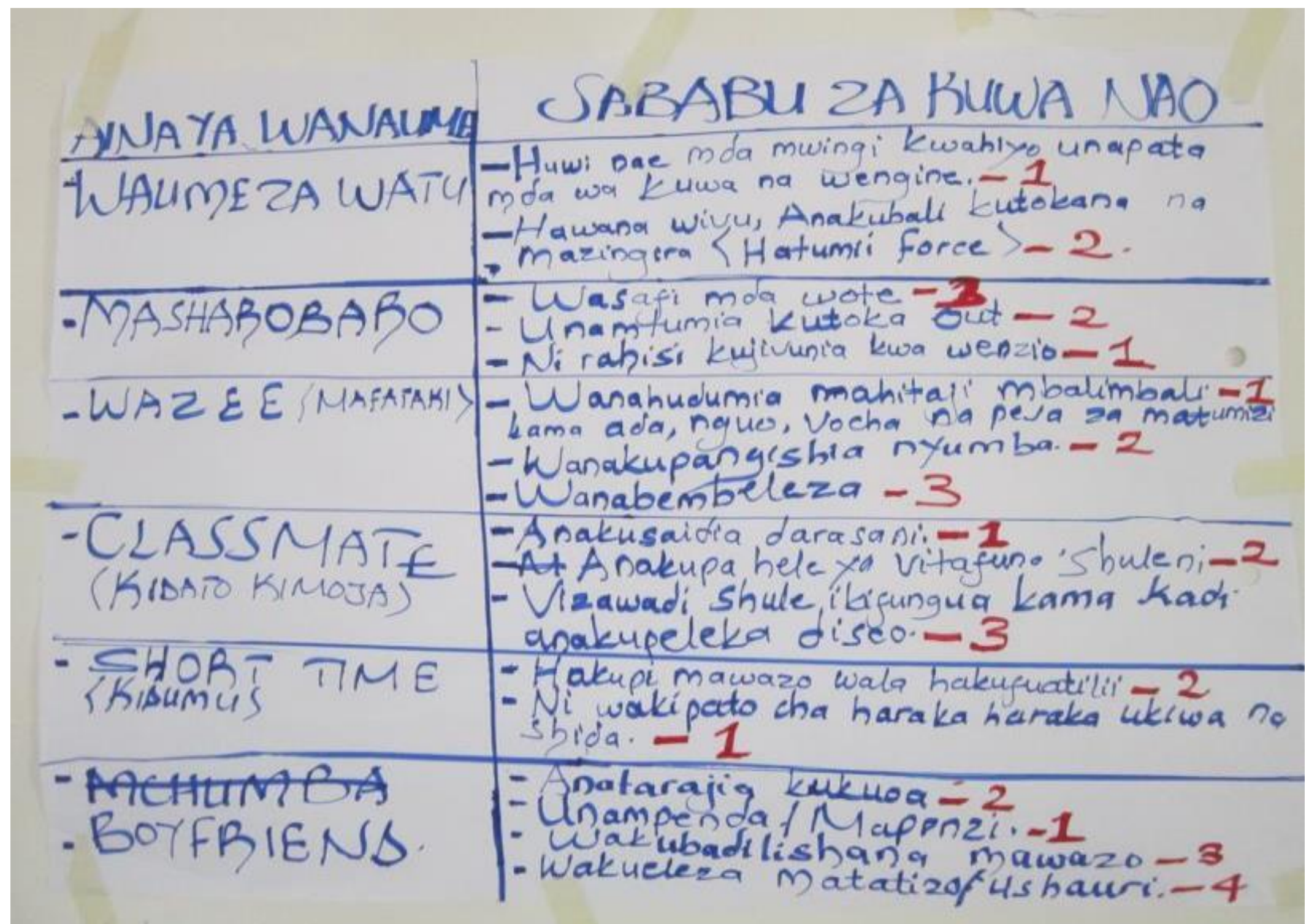

38 


\begin{tabular}{|c|c|c|c|c|c|c|}
\hline \multicolumn{7}{|c|}{$\begin{array}{l}\text { Table 12. Facilitator's recording of ranking exercise features - Mbeya } \\
\text { Directions: List each person noted in the Ranking Exercise - order the list so that the person mentioned the first is at the top and the last is at } \\
\text { the bottom of the PERSON TYPE column. Record the reasons girls have sexual relationships with him and write down any other important } \\
\text { notes about that person. } \\
\text { Location and group type: Mbeya community volunteers } \\
\text { Date: } 15 / 04 / 2015\end{array}$} \\
\hline \multirow[b]{2}{*}{$\begin{array}{l}\text { PERSON TYPE } \\
\text { (listed in order } \\
\text { mentioned) }\end{array}$} & \multicolumn{5}{|c|}{ REASONS FOR HAVING SEXUAL RELATIONSHIP } & \multirow[b]{2}{*}{$\begin{array}{c}\text { NOTES ABOUT THIS } \\
\text { PERSON TYPE }\end{array}$} \\
\hline & Most important & $\begin{array}{l}\text { Second most } \\
\text { important }\end{array}$ & $\begin{array}{l}\text { Third most } \\
\text { important }\end{array}$ & $\begin{array}{l}\text { Fourth } \\
\text { most } \\
\text { important }\end{array}$ & $\begin{array}{l}\text { Fifth most } \\
\text { important }\end{array}$ & \\
\hline Older people & $\begin{array}{l}\text { They offer more } \\
\text { money than others }\end{array}$ & $\begin{array}{l}\text { They have comforting } \\
\text { words }\end{array}$ & & & & $\begin{array}{l}\text { These are old age men either } \\
\text { married or not married. }\end{array}$ \\
\hline $\begin{array}{l}\text { Masharobaro } \\
\text { (young boys) }\end{array}$ & $\begin{array}{l}\text { They wear nice } \\
\text { clothes }\end{array}$ & $\begin{array}{l}\text { They are neat most of } \\
\text { the time; they might } \\
\text { change clothes } 3 \\
\text { times a day }\end{array}$ & & & & $\begin{array}{l}\text { These are kind of show off } \\
\text { boys who don't actually } \\
\text { work. }\end{array}$ \\
\hline Bosses & $\begin{array}{l}\text { For the employment } \\
\text { purposes/chances }\end{array}$ & $\begin{array}{l}\text { They also offer a lot } \\
\text { of money whenever } \\
\text { you need }\end{array}$ & $\begin{array}{l}\text { Its feel like of higher } \\
\text { class in the community } \\
\text { to have relationship } \\
\text { with this kind of man }\end{array}$ & & & $\begin{array}{l}\text { These are actually employed } \\
\text { men, or having position in } \\
\text { working place. }\end{array}$ \\
\hline Drivers & $\begin{array}{l}\text { Just for the ride } \\
\text { from point } A \text { to } \\
\text { point } B \text {. They assist } \\
\text { us on transport }\end{array}$ & $\begin{array}{l}\text { They offer some } \\
\text { small cash when you } \\
\text { are in need }\end{array}$ & & & & $\begin{array}{l}\text { These are both truck drivers } \\
\text { and three wheels, motor } \\
\text { cycle drivers. }\end{array}$ \\
\hline Mabuzi & $\begin{array}{l}\text { Only for purpose of } \\
\text { money no love at all }\end{array}$ & & & & & $\begin{array}{l}\text { These are men considered to } \\
\text { have some cash to spend } \\
\text { with women. }\end{array}$ \\
\hline Kidumu & $\begin{array}{l}\text { They know how to } \\
\text { make love/ sex style } \\
\text { and energy }\end{array}$ & $\begin{array}{l}\text { Just for comfort } \\
\text { words }\end{array}$ & & & & $\begin{array}{l}\text { These are like spare tires; } \\
\text { they go along with the main } \\
\text { boyfriend or husband. They } \\
\text { are the side men. }\end{array}$ \\
\hline Boyfriend & For the future plans & $\begin{array}{l}\text { We exchange and } \\
\text { share ideas and } \\
\text { problems with them }\end{array}$ & & & & $\begin{array}{l}\text { These are the permanent } \\
\text { relationship; they might end } \\
\text { in living together. }\end{array}$ \\
\hline
\end{tabular}


Figure 14. Community volunteers' ranking of motivations for sexual partners - Mbeya

Waz:ti $\rightarrow$ Wanatoa huduma za kutosha kama Uile

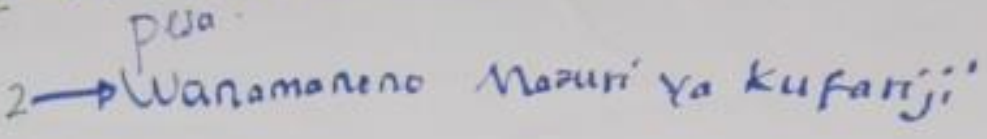

Vijana $\rightarrow$ Kwa Sababu ya Usafi wa Mwili.

$\rightarrow$ La. Kababu ya Usaf, wo havaz, Kiujum

Mabosil $\rightarrow$ Kwa ajili ya kumpatia ajila.

$3 \rightarrow$ Kutaka sifa na kujikuza inwenyeure.
$2 \rightarrow$ Na pia wanatoa pesa nyingi.

Madeleva Kua ajili ya Kupata lift

2 Luva ajili ra kupata Vipesa Vidogo

MabuzI' I Kwa ajil ya Kumchuna persa

kidumu' $\rightarrow$ Kwa ajili ra Mapigo Makali.

2- Kwa ajili ya Kumfarj,:

Boy friendz $\rightarrow$ Kwa ajili ya Kujiwekea Malengo

1 Kwa ajili ya kubadicushona Mawazo. na

Kupanga kuwa wenzi watanj; wa 


\section{Reflections on the dynamics of the two workshops}

The population of community volunteers differed significantly between Dar es Salaam and Iringa/Mbeya. In discussions with Restless Development and UNICEF staff, the facilitators learned that culturally community volunteers in Iringa and Mbeya were a different tribe (Hehe), which has strict prescribed behavior for women speaking in front of men, does not promote schooling for girls, and is more accepting of early marriage. In addition, the region is much more stoic in expressing emotion, and it was difficult at first to gauge the level of understanding of the participants. These characteristics made dynamics of the training different in each context.

Demographically, the groups also differed. The Iringa community volunteers all had children, whereas most of the Dar es Salaam community volunteers did not. The Iringa community volunteers mostly dropped out of school because of Tanzanian law disallowing pregnant adolescent girls from returning to school, or they were taken out at an early age because of Hehe cultural norms. Most of the Dar es Salaam community volunteers did not have children and dropped out of school at a later age than the rural girls, and largely because of poverty and/or being orphans. As a result, the Dar es Salaam community volunteers tended to have a higher level of education, some even completing secondary, which explains why they seemed more accustomed to the structure of workshops and understood the material more quickly. In contrast, many of the Iringa community volunteer attendees had not completed even primary, especially among the Mbeya participants. The cultural and educational factors led to different engagement with the material. These differences were also bolstered by challenges faced within the MTH program of providing support to the more geographically remote Mbeya community volunteers. 


\section{Discussion of key results}

Training in and application of the four tools with the three community volunteer groups revealed a host of challenges, as well as a couple opportunities, among out-of-school girls with regard to their access to safe spaces in the community; the risks of their limited livelihood strategies; ability to obtain financial and health services; connections, power and trust with key individuals; and their motivations for engaging in different types of sexual relationships.

\section{Access to safe spaces in the community}

Out-of-school adolescent girls in both the urban and rural settings reported there was no safe place to socialize and meet with friends, especially at night. The only places were bars, clubs and in Dar a video viewing room. All these spaces were highly populated by boys and men and often had a lot of alcohol around. In one case the stakeholders in the workshop were surprised that out-of-school girls went so often to such unsafe places; the community volunteers were resolute, however, and informed the stakeholders that yes they do because there was no other place to go in the evening.

Out of school girls' livelihoods were dominated by petty trading and dependence on male sexual partners (the latter described below). Petty trading involved moving about the community, often in unsafe places, and carried risks. Girls went to the market daily in Dar to sell goods and procure their material needs; male shopkeepers there were said to be verbally abusive and disrespectful to out-of-school girls. Iringa participants reported a male secondhand clothing merchant who often provided the apparel in exchange for sex with out-of-school girls. The Mbeya participants said they frequented residential areas to sell their wares and men there often tried to lure them into houses or hidden areas to engage in sex acts. In Dar, girls reported selling their goods at a primary school. Male teachers were described as seeing no problem with having sex with and impregnating out-of-school girls; because the girls are no longer students the teachers are not punished for having these relationships.

\section{Ability to obtain financial and health services}

Despite their lack of livelihood options out-of-school girls were described as having remarkably poor access to any individual or group savings or micro-loan programs. In Dar a formal bank was mentioned in the Venn diagram exercise but ranked with low importance because it served so few girls. The Iringa group did not mention any microfinance institution; of the seven institutions described in Mbeya, three had financial programming content but only one offered even minor services to adolescent girls. In both Dar and Iringa, one entrepreneurial and/or vocational training organization was mentioned that out-of-school girls had access to. No training was described in Mbeya.

All three mentioned at least one HIV support organization in their Venn diagram that was important, trusted and accessible to out-of-school girls. An interesting case reported in Dar was that out-of-school girls who were members of an MTH girl group were described as having 
better access services at the hospital than other out-of-school girls. Besides MTH girls having more confidence and knowledge, it may have also been the case that the hospital felt more accountable to them because these girls had an advocate in their female MTH group leader.

Of all the organizations discussed in the three Venn diagrams, Restless Development was without a doubt the most important, trusted and accessible organization for out-of-school girls.

$\underline{\text { Trust, power and linkages with key individuals }}$

In the urban area, mothers were reported as being the most trusted, powerful and close person to out-of-school girls; in the rural communities these favorable traits were used to describe both mothers and fathers. In the Dar and Iringa groups, sisters and female friends were reported as not being trustworthy.

In Iringa, shopkeepers and government officials were described as being disrespectful to out-ofschool girls; in Mbeya religious leaders and primary school teachers were reported to actively seek out sexual relationships with out-of-school girls. In Dar there was less sexual harassment and predation of out-of-school girls described.

In all three groups, the young women spoke with confidence in the plenary sessions about different types of people in the community who did not respect or openly abused out-of-school girls. The young women were very brave and straightforward in their descriptions.

\section{Motivations for having different types of sexual partners}

In each of the three groups, six or seven distinct sexual partner types of out-of-school girls were described. In each case, participants provided between one and five reasons for engaging in that type of relationship.

Married men, very old men, kidumu (gallon, or side partner), a man you meet only for sex when you need fast money, and boyfriend were all mentioned in the urban and rural settings and the motivations for partnering with each were similar across the three regions. The one night stand ("show time/take away") was described in Dar and Iringa but not Mbeya.

Not talked about in Dar but listed by both the Iringa and Mbeya community volunteers was the category of masharobaro - or show off boys. These are young men who do not work, dress and

groom themselves neatly, change clothes several times per day, and are desirable for girls to be seen with in the community.

Unique to the Mbeya group's list were drivers and "bosses". Drivers were reported as prominent partners for out-of-school girls in Mbeya because rural transport is such a large challenge and drivers provide lifts in exchange for sex. Bosses were described as men who are in the formal workforce and give girls hope for employment, money when girls need it, and social prestige when seen being out with him in the community. 
Age-mate, "real love" boyfriends were mentioned toward the bottom of all three of the groups' lists. They differed greatly from the other partner types, who were mostly older (in some cases much older) than the girls and used primarily as sources of money, and to a lesser extent social prestige and companionship.

We did not probe for, nor did we hear any comments about condom use dynamics with any of the sexual partners the girls described.

\section{Recommendations}

Based on our training and application of the four participatory tools with the three groups of MTH community volunteers, the findings indicate that out-of-school adolescent girls need more access to:

- Safe spaces in the community to socialize with other girls, particularly in the evenings

- Opportunities for entrepreneurial and vocational training

- Financial education training

- Individual and group savings schemes, and for those who are ready, microloans

- Health knowledge and a backstopping advocate for increasing their access to safe and appropriate health services

- Discussions with girls around condom use, condom availability, and sexual partner reduction so that girls can minimize their risks. Boys and men should be engaged in such discussions. An on-going series of single- and mixed-sex discussion groups should take place in each community.

- Affordable and safe (perhaps female owned and operated) transportation options, especially in Mbeya 
Appendices

I. Dar es Salaam workshop agenda

II. Iringa workshop agenda 
Mabinti Tushike Hatamu

Participatory Tools Training Agenda

Dar es Salaam, Tanzania

8-10 April 2015

Workshop Agenda

Day 1

\begin{tabular}{|c|c|c|}
\hline Time & Lead & Activity \\
\hline $\begin{array}{l}8: 30-9 a m \\
30 \text { minutes }\end{array}$ & $\begin{array}{l}\text { Restless } \\
\text { Development }\end{array}$ & Registration \\
\hline $\begin{array}{l}\text { 9-9:45am } \\
45 \text { minutes }\end{array}$ & Ilan & Introduction and Panel \\
\hline $\begin{array}{l}\text { 9:45-10:00am } \\
15 \text { minutes }\end{array}$ & Ilan & What is a participatory tool? \\
\hline $\begin{array}{l}\text { 10-10:30am } \\
30 \text { minutes }\end{array}$ & Kelly & Introduction of four primary tools \\
\hline $\begin{array}{l}\text { 10:30-10:45am } \\
15 \text { minutes }\end{array}$ & & Coffee break \\
\hline $\begin{array}{l}\text { 10:45-11:00am } \\
15 \mathrm{~min}\end{array}$ & Ilan & Introduction to observation checklist \\
\hline $\begin{array}{l}\text { 11:00-11:30am } \\
30 \text { minutes }\end{array}$ & Kelly & Community Mapping (introduction) \\
\hline $\begin{array}{l}11: 30 \mathrm{am}-12: 30 \mathrm{pm} \\
60 \text { minutes }\end{array}$ & Kelly & Community Mapping plenary exercise \\
\hline $\begin{array}{l}12: 30-1: 30 \mathrm{pm} \\
60 \text { minutes }\end{array}$ & & Lunch \\
\hline $\begin{array}{l}1: 30-1: 45 \mathrm{pm} \\
15 \text { minutes }\end{array}$ & Ilan & Energizer \\
\hline $\begin{array}{l}\text { 1:45-2:00pm } \\
15 \text { minutes }\end{array}$ & Ilan & What is good facilitation? \\
\hline $\begin{array}{l}2.00-3.00 \\
60 \text { minutes }\end{array}$ & Neema/Omari/llan & $\begin{array}{l}\text { Community Mapping small group } \\
\text { practice }\end{array}$ \\
\hline $\begin{array}{l}3.00-3.15 \mathrm{pm} \\
15 \text { minutes }\end{array}$ & & Coffee break \\
\hline $\begin{array}{l}3.15-4.30 \\
75 \text { minutes }\end{array}$ & Neema & Groups report back and discuss \\
\hline $\begin{array}{l}4: 30-4: 45 \\
15 \text { minutes }\end{array}$ & Ilan/Omari & Wrap-up of day \\
\hline
\end{tabular}


Dar es Salaam, Day 2

\begin{tabular}{|c|c|c|}
\hline Time & & Activity \\
\hline $\begin{array}{l}8: 30-9 a m \\
30 \text { minutes }\end{array}$ & Ilan & Check-in with participants/energizer \\
\hline $\begin{array}{l}9-9.30 \mathrm{am} \\
30 \text { minutes }\end{array}$ & Ilan & Venn Diagram (Introduction) \\
\hline $\begin{array}{l}9: 30-10: 30 a m \\
60 \text { minutes }\end{array}$ & Kelly & Venn Diagram plenary exercise \\
\hline $\begin{array}{l}10.30-11.30 \mathrm{am} \\
60 \text { minutes }\end{array}$ & Neema/Omari/llan & Venn Diagram small group practice \\
\hline $\begin{array}{l}11: 30-11: 45 \mathrm{pm} \\
15 \text { minutes }\end{array}$ & & Coffee break \\
\hline $\begin{array}{l}11.45-1 \mathrm{pm} \\
75 \text { minutes }\end{array}$ & Neema & Groups report back and discuss \\
\hline $\begin{array}{l}1-2 \mathrm{pm} \\
60 \text { minutes }\end{array}$ & & Lunch \\
\hline $\begin{array}{l}2-2: 15 \mathrm{pm} \\
15 \text { minutes }\end{array}$ & Omari & Energizer \\
\hline $\begin{array}{l}2: 15-2: 45 \\
30 \text { minutes }\end{array}$ & Ilan & Social Capital Game (Introduction) \\
\hline $\begin{array}{l}\text { 2:45-3:30pm } \\
45 \text { minutes }\end{array}$ & Kelly & Social Capital Game plenary exercise \\
\hline $\begin{array}{l}3: 30-3: 45 \\
15 \text { minutes }\end{array}$ & & Coffee break \\
\hline $\begin{array}{l}3: 45-4: 45 \mathrm{pm} \\
60 \text { minutes }\end{array}$ & Neema & Social Capital Game small group practice \\
\hline $\begin{array}{l}4: 45-5 \mathrm{pm} \\
15 \text { minutes }\end{array}$ & Kelly/Omari & Wrap-up of day \\
\hline
\end{tabular}


Dar es Salaam, Day 3

\begin{tabular}{|c|c|c|}
\hline Time & & $\begin{array}{c}\text { Activity } \\
\end{array}$ \\
\hline $\begin{array}{l}8: 30-9 \mathrm{am} \\
30 \text { minutes }\end{array}$ & Neema & Check-in with participants/energizer \\
\hline $\begin{array}{l}9.00-10.15 a m \\
75 \text { minutes }\end{array}$ & Neema/Omari & $\begin{array}{l}\text { Groups report back and discuss (Social } \\
\text { Capital Game) }\end{array}$ \\
\hline $\begin{array}{l}10: 15-10: 45 a m \\
30 \text { minutes }\end{array}$ & Ilan & Introduction to Ranking Exercise \\
\hline $\begin{array}{l}\text { 10:45-11:00am } \\
15 \text { minutes }\end{array}$ & & Coffee break \\
\hline $\begin{array}{l}\text { 11:00am-12:00pm } \\
60 \text { minutes }\end{array}$ & Kelly & Ranking Exercise plenary exercise \\
\hline $\begin{array}{l}12.00-1.00 \mathrm{pm} \\
60 \text { minutes }\end{array}$ & Omari/Neema/llan & Ranking Exercise small group practice \\
\hline $\begin{array}{l}\text { 1:00-2:00pm } \\
60 \text { minutes }\end{array}$ & & Lunch \\
\hline $\begin{array}{l}2: 00-2: 15 p m \\
15 \text { minutes }\end{array}$ & Neema & Energizer \\
\hline $\begin{array}{l}2: 15-2: 45 \mathrm{pm} \\
30 \text { minutes }\end{array}$ & Kelly & Scenarios: Difficult moments to facilitate \\
\hline $\begin{array}{l}\text { 2:45-3:00pm } \\
15 \text { minutes }\end{array}$ & & Coffee break \\
\hline $\begin{array}{l}3: 00-4: 15 \mathrm{pm} \\
75 \text { minutes }\end{array}$ & Omari/Neema & $\begin{array}{l}\text { Groups report back and discuss on } \\
\text { Ranking Exercise }\end{array}$ \\
\hline $\begin{array}{l}4: 15-4: 45 \mathrm{pm} \\
30 \text { minutes }\end{array}$ & Omari & $\begin{array}{l}\text { Overall reflection and discussion of } \\
\text { tools, evaluation of training }\end{array}$ \\
\hline $\begin{array}{l}4: 45-5: 00 p m \\
15 \text { minutes }\end{array}$ & Ilan, Kelly & Closing Remarks \\
\hline
\end{tabular}




\section{Mabinti Tushike Hatamu}

\section{Participatory Tools Training Agenda}

Iringa, Tanzania

\section{3-15 April 2015}

\section{Workshop Agenda}

Day 1

\begin{tabular}{|c|c|c|}
\hline Time & Lead & Activity \\
\hline $\begin{array}{l}8: 30-9 \mathrm{am} \\
30 \text { minutes }\end{array}$ & $\begin{array}{l}\text { Restless } \\
\text { Development }\end{array}$ & Registration \\
\hline $\begin{array}{l}9-10 a m \\
60 \text { minutes }\end{array}$ & Kelly/Philip/Neema & Introduction, Energizer, and Panel \\
\hline $\begin{array}{l}10-10: 15 a m \\
15 \text { minutes }\end{array}$ & Kelly & Introduction of four primary tools \\
\hline $\begin{array}{l}10: 15-10: 30 \mathrm{am} \\
15 \text { minutes }\end{array}$ & Ilan & What is a participatory tool? \\
\hline $\begin{array}{l}\text { 10:30-10:45am } \\
15 \text { minutes }\end{array}$ & & Coffee break \\
\hline $\begin{array}{l}10: 45-11 \mathrm{am} \\
15 \text { minutes }\end{array}$ & Ilan & What is good facilitation? \\
\hline $\begin{array}{l}11-11: 15 a m \\
15 \text { minutes }\end{array}$ & Kelly & Community Mapping (introduction) \\
\hline $\begin{array}{l}11: 15 \mathrm{am}-12: 15 \mathrm{pm} \\
60 \text { minutes }\end{array}$ & Kelly & Community Mapping plenary exercise \\
\hline $\begin{array}{l}12: 15-1: 15 \mathrm{pm} \\
60 \text { minutes }\end{array}$ & & Lunch \\
\hline $\begin{array}{l}1: 15-1: 30 \mathrm{pm} \\
15 \text { minutes }\end{array}$ & Neema & Energizer \\
\hline $\begin{array}{l}1: 30-1: 45 \mathrm{pm} \\
15 \mathrm{~min}\end{array}$ & Ilan & $\begin{array}{l}\text { Introduction to good facilitation } \\
\text { checklist and other roles in groups }\end{array}$ \\
\hline $\begin{array}{l}1: 45-2: 45 \mathrm{pm} \\
60 \text { minutes }\end{array}$ & Neema/Philip & $\begin{array}{l}\text { Community Mapping small group } \\
\text { practice }\end{array}$ \\
\hline $\begin{array}{l}2: 45-3: 00 p m \\
15 \text { minutes }\end{array}$ & & Coffee break \\
\hline $\begin{array}{l}3: 00-4: 15 p m \\
75 \text { minutes }\end{array}$ & Neema/Philip & Groups report back and discuss \\
\hline $\begin{array}{l}4: 15-4: 30 \mathrm{pm} \\
15 \text { minutes }\end{array}$ & Neema/Philip & Wrap-up of day \\
\hline
\end{tabular}


Iringa, Day 2

\begin{tabular}{|c|c|c|}
\hline Time & & Activity \\
\hline $\begin{array}{l}8: 30-9 a m \\
30 \text { minutes }\end{array}$ & Neema/Philip & Check-in with participants/energizer \\
\hline $\begin{array}{l}9-9: 10 a m \\
10 \text { minutes }\end{array}$ & Ilan & Venn Diagram (Introduction) \\
\hline $\begin{array}{l}\text { 9:10-10am } \\
50 \text { minutes }\end{array}$ & Kelly & Venn Diagram plenary exercise \\
\hline $\begin{array}{l}\text { 10-11:00am } \\
60 \text { minutes }\end{array}$ & Neema/Philip & Venn Diagram small group practice \\
\hline $\begin{array}{l}\text { 11-11:15am } \\
15 \text { minutes }\end{array}$ & & Coffee break \\
\hline $\begin{array}{l}11.15-12: 30 p m \\
75 \text { minutes }\end{array}$ & Neema/Philip & Groups report back and discuss \\
\hline $\begin{array}{l}12: 30-1: 30 \mathrm{pm} \\
60 \text { minutes }\end{array}$ & & Lunch \\
\hline $\begin{array}{l}1: 30-1: 45 p m \\
15 \text { minutes }\end{array}$ & Philip & Energizer \\
\hline $\begin{array}{l}1: 45-2 \mathrm{pm} \\
15 \text { minutes }\end{array}$ & Ilan & Introduction to social capital \\
\hline $\begin{array}{l}2-3: 00 p m \\
60 \text { minutes }\end{array}$ & Kelly & Social capital game plenary exercise \\
\hline $\begin{array}{l}3-3: 15 p m \\
15 \text { minutes }\end{array}$ & & Coffee break \\
\hline $\begin{array}{l}3: 15-4: 15 p m \\
60 \text { minutes }\end{array}$ & Neema/Philip & Social capital game small group practice \\
\hline $\begin{array}{l}4: 15-4: 30 p m \\
15 \text { minutes }\end{array}$ & Neema/Philip & Wrap-up of day \\
\hline
\end{tabular}


Iringa, Day 3

\begin{tabular}{|l|l|l|}
\hline \multicolumn{1}{|c|}{ Time } & & \multicolumn{1}{c|}{ Activity } \\
\hline $\begin{array}{l}\text { 8:30-9am } \\
30 \text { minutes }\end{array}$ & Neema/Philip & Check-in with participants/energizer \\
\hline $\begin{array}{l}\text { 9.00-10.15am } \\
75 \text { minutes }\end{array}$ & Neema/Philip & $\begin{array}{l}\text { Groups report back and discuss } \\
\text { (social capital) }\end{array}$ \\
\hline $\begin{array}{l}\text { 10:15-10:45am } \\
30 \text { minutes }\end{array}$ & Ilan & $\begin{array}{l}\text { Scenarios: Difficult moments to } \\
\text { facilitate }\end{array}$ \\
\hline $\begin{array}{l}10: 45-11 \mathrm{am} \\
15 \text { minutes }\end{array}$ & & $\begin{array}{l}\text { Coffee break; } \\
\text { Stakeholders depart }\end{array}$ \\
\hline $\begin{array}{l}11-11: 15 \mathrm{am} \\
15 \text { minutes }\end{array}$ & Kelly & Introduction to ranking exercise \\
\hline $\begin{array}{l}11: 15 \mathrm{am}-12: 15 \mathrm{pm} \\
60 \text { minutes }\end{array}$ & Kelly & Ranking exercise plenary exercise \\
\hline $\begin{array}{l}12: 15-12: 30 \mathrm{pm} \\
\text { 12.30-1.30pm } \\
60 \text { minutes }\end{array}$ & Neema & Energizer \\
\hline $\begin{array}{l}1: 30-2: 15 \mathrm{pm} \\
45 \text { minutes }\end{array}$ & Neema/Philip & $\begin{array}{l}\text { Ranking exercise small group } \\
\text { practice }\end{array}$ \\
\hline $\begin{array}{l}2: 15-2: 30-\mathrm{pm} \\
15 \text { minutes }\end{array}$ & Philip & Groups report back and discuss \\
\hline $\begin{array}{l}2: 30-2: 45 \mathrm{pm} \\
15 \text { minutes }\end{array}$ & Neema/Philip/Kelly/llan & Closing remarks \\
\hline
\end{tabular}

